\title{
Injury of the Inferior Alveolar Nerve during Implant Placement: a Literature Review
}

\author{
Gintaras Juodzbalys ${ }^{1}$, Hom-Lay Wang ${ }^{2}$, Gintautas Sabalys ${ }^{1}$ \\ ${ }^{1}$ Department of Oral and Maxillofacial Surgery, Lithuanian University of Health Sciences, Kaunas, Lithuania. \\ ${ }^{2}$ Department of Periodontics and Oral Medicine, University of Michigan, Ann Arbor Michigan, USA.
}

\author{
Corresponding Author: \\ Gintaras Juodzbalys \\ Vainiku 12 \\ LT- 46383, Kaunas \\ Lithuania \\ Phone: +370 37297055 \\ Fax: +370 37323153 \\ E-mail: gintaras@stilusoptimus.1t
}

\begin{abstract}
Objectives: The purpose of present article was to review aetiological factors, mechanism, clinical symptoms, and diagnostic methods as well as to create treatment guidelines for the management of inferior alveolar nerve injury during dental implant placement.

Material and Methods: Literature was selected through a search of PubMed, Embase and Cochrane electronic databases. The keywords used for search were inferior alveolar nerve injury, inferior alveolar nerve injuries, inferior alveolar nerve injury implant, inferior alveolar nerve damage, inferior alveolar nerve paresthesia and inferior alveolar nerve repair. The search was restricted to English language articles, published from 1972 to November 2010. Additionally, a manual search in the major anatomy, dental implant, periodontal and oral surgery journals and books were performed. The publications there selected by including clinical, human anatomy and physiology studies.

Results: In total 136 literature sources were obtained and reviewed. Aetiological factors of inferior alveolar nerve injury, risk factors, mechanism, clinical sensory nerve examination methods, clinical symptoms and treatment were discussed. Guidelines were created to illustrate the methods used to prevent and manage inferior alveolar nerve injury before or after dental implant placement.

Conclusions: The damage of inferior alveolar nerve during the dental implant placement can be a serious complication. Clinician should recognise and exclude aetiological factors leading to nerve injury. Proper presurgery planning, timely diagnosis and treatment are the key to avoid nerve sensory disturbances management.
\end{abstract}

Keywords: mandibular nerve; alveolar nerve, inferior; mandibular canal; cranial nerve injuries; paresthesia; dental implants.

\author{
Accepted for publication: 10 January 2011 \\ To cite this article: \\ Juodzbalys G, Wang HL, Sabalys G. Injury of the Inferior Alveolar Nerve during Implant Placement: a Literature Review. \\ J Oral Maxillofac Res 2011 (Jan-Mar);2(1):e1 \\ URL: http://www.ejomr.org/JOMR/archives/2011/1/e1/v2n1e1ht.pdf \\ doi: $10.5037 /$ jomr.2011.2101
}




\section{INTRODUCTION}

In 1995 Worthington wrote: "The number of practitioners performing implant surgery has increased dramatically over the last fifteen years. As confidence is gained they tend to accept increasingly challenging cases and it is to be expected that the incidence of problems and complications will increase" [1]. It was discerning remark, however, it remains a serious complication and many had reported the incidence, varies from 0 to $40 \%$, of implant related inferior alveolar nerve (IAN) injuries [2-16]. The damage can result from the traumatic local anaesthetic injections or during the dental implant site osteotomy or placement [12]. This damage is one of the most unpleasant experiences, from mild paresthesia to complete anaesthesia and/or pain [15], for both the patient and the dentist. As a result, many functions such as speech, eating, kissing, make-up application, shaving and drinking will be affected $[\underline{8}]$.

The IAN supplies the mandibular molar and premolar teeth and adjacent parts of the gingival. Its larger terminal branch emerges from the mental foramen as the mental nerve. Three nerve branches come out of the mental foramen. One innervates the skin of the mental area, and the other two proceed to the skin of the lower lip, mucous membranes, and the gingiva as far posteriorly as the second premolar. The incisive branch, a continuation of the IAN, supplies the canine and incisor teeth $[\underline{8}, \underline{10}]$.

It is interesting to know that the IAN is most commonly injured nerve $(64.4 \%)$, followed by the lingual nerve $(28.8 \%)$ [13]. The differences between IAN injuries and other peripheral sensory nerve injuries, are predominantly iatrogenic and not resolved within the first 8 weeks after injury. The closed injuries can also occur that often delays diagnosis and treatment [17]. This injury influences patient's quality of life and the iatrogenesis of these damages compound the negative psychological effects of these injuries [10]. Once it happens, the dentist should provide the appropriate care and treatment to the patient, as soon as it is possible.

The authors of this review paper have previously published a series of articles related to the mandibular vital structures anatomy, techniques available for identifying of these structures and make the recommendations of how to avoid nerve damage, when performing oral implants [18-20]. The best way to prevent these damages is to have clear three-dimensional vision of the jaw. This can be achieved by combining the practical knowledge of basic mandibular anatomy and the data obtained from clinical and radiological examination. Currently, guidelines for the management of implant related nerve injury is lacking. Therefore, the purpose of present article were to review aetiological factors, mechanism, clinical symptoms, diagnostic methods and treatment as well as to create guidelines for the management of inferior alveolar nerve injury before or after dental implant placement.

\section{MATERIAL AND METHODS}

Literature was selected through a search of PubMed, Embase and Cochrane electronic databases. The keywords used for search were inferior alveolar nerve injury, inferior alveolar nerve injuries, inferior alveolar nerve injury implant, inferior alveolar nerve damage, inferior alveolar nerve paresthesia and inferior alveolar nerve repair. The search was restricted to English language articles, published from 1972 to November 2010. Additionally, a manual search in the major anatomy, dental implant, periodontal and oral surgery journals and books were performed. The publications there selected by including clinical and human anatomy as well as physiology studies.

\section{Aetiological factors of traumatic inferior alveolar nerve injury}

Table 1 shows possible aetiological factors of IAN injury during the implant placement. Aetiological factors of IAN injury depending on the time of incident can be classified into intraoperative and postoperative. Depending on traumatic mechanism intraoperative aetiological factors may be further sub-grouped into mechanical, thermal and chemical and postoperative indirect - to thermal stimuli, periimplant infection and hematoma with subsequent scaring and ischemia.

Mechanical traumatic factors are as follows: injection needle, implant drill, implant itself or bone debris (foreign body) and/or hematoma in the mandibular canal (MC) below the implant, scalpel, soft tissue retraction instruments. All mechanical factors may evoke direct mechanical injury i.e. pressure, encroach, transection, or laceration of the nerve. Or in case of partial intrusion of the drill or dental implant into MC intraoperative as well as indirect nerve injury due to hematoma, compression and secondary ischemia.

Chemical and thermal intraoperative aetiological factors will cause direct nerve structures destruction. Indirect postoperative thermal and infection aetiological factors will cause inflammation, secondary ischemia with subsequent degeneration of the nerve structures. Hematoma can cause tissue scaring and secondary ischemia of neurovascular bundle with subsequent nerve degeneration. 
Table 1. Aetiological factors and mechanism of traumatic inferior alveolar nerve injury [21-82]

\begin{tabular}{|c|c|c|c|}
\hline $\begin{array}{c}\text { Intraoperative } \\
\text { aetiological factor }\end{array}$ & Indirect or direct; mechanism & $\begin{array}{c}\text { Postoperative } \\
\text { aetiological factor }\end{array}$ & Indirect; mechanism \\
\hline \multicolumn{4}{|c|}{ Traumatic local anaesthesia } \\
\hline $\begin{array}{l}\text { Chemical } \\
\text { (cytotoxic) injury by } \\
\text { local anaesthetic }\end{array}$ & $\begin{array}{l}\text { Indirect; endoneurial oedema, compression } \\
\text { and secondary ischemia } \\
\text { Direct; IAN degeneration }\end{array}$ & \multirow{2}{*}{$\begin{array}{l}\text { Injection needle trauma to } \\
\text { epineurial blood vessels } \\
\text { or inferior alveolar artery }\end{array}$} & \multirow{2}{*}{$\begin{array}{l}\text { Indirect; hematoma with reactive } \\
\text { fibrosis and scar formation, } \\
\text { compression and secondary ischemia }\end{array}$} \\
\hline Injection needle & $\begin{array}{l}\text { Direct; transection of multiple IAN fibres } \\
\text { and entire fascicles }\end{array}$ & & \\
\hline \multicolumn{4}{|c|}{ Implant drill } \\
\hline $\begin{array}{l}\text { Partial intrusion into } \\
\mathrm{MC}\end{array}$ & $\begin{array}{l}\text { Indirect; hematoma and secondary } \\
\text { ischemia }\end{array}$ & \multirow{4}{*}{ Thermal injury } & \multirow{4}{*}{$\begin{array}{l}\text { Indirect; inflammation of bone and } \\
\text { IAN with secondary ischemia }\end{array}$} \\
\hline $\begin{array}{l}\text { Full intrusion into } \\
\mathrm{MC}\end{array}$ & $\begin{array}{l}\text { Direct; mechanical trauma - encroach, } \\
\text { transection, or laceration and/or } \\
\text { compression and primary ischemia of IAN }\end{array}$ & & \\
\hline $\begin{array}{l}\text { Chemical } \\
\text { (cytotoxic) injury by } \\
\text { irrigation solution }\end{array}$ & Direct; IAN degeneration & & \\
\hline Thermal injury & Direct; IAN degeneration & & \\
\hline \multicolumn{4}{|c|}{ Dental implant } \\
\hline \multirow{2}{*}{$\begin{array}{l}\text { Partial intrusion into } \\
\mathrm{MC}\end{array}$} & \multirow{2}{*}{$\begin{array}{l}\text { Indirect; hematoma or/and deposition } \\
\text { of debris, compression and secondary } \\
\text { ischemia }\end{array}$} & Infection & $\begin{array}{l}\text { Indirect; inflammation of bone and } \\
\text { IAN with secondary ischemia }\end{array}$ \\
\hline & & \multirow{2}{*}{$\begin{array}{l}\text { Implant is too close to } \\
\mathrm{MC}\end{array}$} & \multirow{2}{*}{$\begin{array}{l}\text { Indirect; bone and IAN stress, } \\
\text { compression with secondary ischemia }\end{array}$} \\
\hline \multirow[b]{2}{*}{$\begin{array}{l}\text { Full intrusion into } \\
\mathrm{MC}\end{array}$} & \multirow[b]{2}{*}{$\begin{array}{l}\text { Direct; mechanical trauma - encroach, } \\
\text { transection, or laceration and/or } \\
\text { compression and primary ischemia of IAN }\end{array}$} & & \\
\hline & & Chronic stimulation & $\begin{array}{l}\text { Indirect; implant is situated aside of } \\
\text { or on top of the nerve with chronic } \\
\text { neuropathy formation }\end{array}$ \\
\hline \multicolumn{4}{|c|}{$\begin{array}{l}\text { Wrong operation technique } \\
\end{array}$} \\
\hline Scalpel & Direct; mental nerve injury or transection & \multirow{3}{*}{ Soft tissue swelling } & \multirow{3}{*}{$\begin{array}{l}\text { Indirect; mental nerve compression } \\
\text { caused by soft tissue oedema }\end{array}$} \\
\hline $\begin{array}{l}\text { Soft tissue reflection } \\
\text { and retraction }\end{array}$ & $\begin{array}{l}\text { Direct; mental nerve injury caused by } \\
\text { reflection, retraction and pressure }\end{array}$ & & \\
\hline Soft tissue suturing & $\begin{array}{l}\text { Direct; mental nerve compression caused } \\
\text { by suture material }\end{array}$ & & \\
\hline
\end{tabular}

\section{Inferior alveolar nerve injury during traumatic local anaesthesia injection}

Profound local anaesthesia during the dental implant surgery can drastically reduce patient anxiety during the surgery. Local anaesthetics are designed to prevent sensory impulses being transmitted from intraoral and extraoral areas to the central nervous system with minimal effect on muscular tone [21]. Unfortunately, the injury of an IAN can occur during a traumatic local anaesthesia injection [22]. Although very rare, nerve injury after administration of an IAN block was well documented [23-37]. The exact mechanism of the injury has yet to be determined [34], nevertheless. Three main theories were proposed. These include direct trauma from the injection needle $[27,33,38,39]$, hematoma formation $[\underline{24}, \underline{27-29}, \underline{33}, \underline{38}, \underline{39}]$ and neurotoxicity of the local anaesthetic $[\underline{27}, \underline{28}, \underline{31}, \underline{33}, \underline{40-43}]$.
One of the oldest theories is that the needle contacts the nerve directly, thereby traumatizing the nerve and producing a prolonged change in sensation. Performing mandibular block the practitioner contacts bone with the tip of needle to ensure a proper deposition of local anaesthetic and the tip of this needle can become barbed [33]. In one study, $78 \%$ of the long bevelled needles used for conventional mandibular block appeared to be barbed at their tips after the procedure, regardless of bevel placement [38]. More than two-thirds of these needles displayed the more dangerous outward facing barb. These barbs can rupture the perineurium, herniate the endoneurium and cause transection of the multiple nerve fibres and even entire fascicles, especially on withdrawal $[27,38,39]$. Only $1.3-8.6 \%$ of the patients get an "electric shock type" sensation on the application of IAN block and $57 \%$ of the patients suffer from prolonged neuropathy, having not experienced 
the discomfort on injection, thus this is not a specific sign [44].

The second theory is the needle may traumatize the epineurial blood vessels $[27,28,33,38,39]$. Haemorrhage from the epineurial blood vessels would compress the nerve fibres and cause localized neurotoxicity $[\underline{33}, \underline{38}]$. The damage could be extended beyond 30 minutes after injection [28]. The release of blood and blood products from the epineurial blood vessels into the epineurium during hematoma formation would lead to reactive fibrosis and scar formation, applying pressure to and inhibiting the natural healing of the nerve $[\underline{24}, 27,29,33]$. The third theory suggests that the anaesthetic itself causes localized chemical damage to the nerve, if it is injected intrafascicularly or becomes deposited within the nerve as the needle is withdrawn $[33,40,41,45]$. Chemical nerve injury may be related to specific chemical agents and the local anaesthetic components (type of agent, agent concentration, buffer, preservative) [46]. It was shown, that the $4 \%$ prilocaine and $4 \%$ articaine have caused more injuries per use than lidocaine $[27,28,31,33,44]$. It has been reported that $54 \%$ of the nerve injuries during mandibular block $(\mathrm{n}=52)$ were associated with articaine [44]. Articaine has been shown to have 21 times more nerve injuries when compared with local anaesthetic drugs [27]. Similar findings were also reported in the USA and more recently in Canada $[28,30,33]$. Both of the anaesthetics are supplied at higher concentrations, which produce the greater levels of toxic metabolites after the process of metabolism $[\underline{42}, \underline{43}]$. The type of anaesthetic dictates the degree of inflammatory reaction to the local anaesthetic, lidocaine being the least irritant followed by articaine, mepivicaine and bupivicaine [47].

Consequently, it has been hypothesized that aromatic alcohols produced in the area surrounding the nerves is a result of altered local metabolism of the anaesthetic $[\underline{27}, \underline{28}]$. As a result, the nerve-blood barrier breaks down, and endoneurial oedema follows. It was hypothesized that this oedema triggers ischemia as a result of nerve attempt to heal. During this period of reperfusion, reactive free radicals can cause cytotoxic injury to the nerve [42]. Perez-Castro et al., in their in vitro study confirmed that increasing the concentration of local anaesthetic agent can significantly affect the survival rate of neurones [48]. Chemical trauma has been shown to cause demyelination, axonal degeneration and inflammation of the surrounding nerve fibres within the fascicles. However, it is important to know that when used properly, local anaesthetics represent the safest and most effective drugs in all medicine for the prevention and management of pain [49].

Torrente-Castells et al. presented a case report of patient where on the basis of clinical manifestations and affected anatomical structures, postulated a skin necrosis secondary to vascular spasm of the terminal branches of inferior alveolar artery [50]. It was recommended by many authors $[51,52]$ in the placement of mandibular implants, it may be useful for patient to be able to sense when the IAN is in danger of being damaged, possibly producing permanent paresthesia. The technique of local infiltration instead of mandibular block has been advocated. However, this technique is not generally used, arguing that the bone possesses sensitive nerve endings that could cause discomfort during the surgery [ $\underline{53}]$.

\section{Inferior alveolar nerve injury by implant drill}

The most severe types of injuries are caused by implant drills and implants themselves [54]. Sensory IAN injuries made by implant drills may be caused by direct intraoperative (mechanical and chemical) and indirect postoperative trauma (ischemia and thermal stimuli) [55]. Many implant drills are slightly longer, for drilling efficiency, than their corresponding implants. Implant drill length varies and must be understood by the surgeon because the specified length may not reflect an additional millimetre so called " $y$ " dimension [15]. Lack of knowledge about this may cause avoidable complications [56]. Damage to the IAN can occur when the twist drill or implant encroaches, transects, or lacerates the nerve (Figures 1A and B).

Even after the accurate measurement of available bone, the nerve injury can occur as the result of over penetration of the drill (direct intraoperative mechanical trauma) owing to low resistance of the spongy bone; this can lead to slippage of the drill even by experienced surgeons [드]. It is interesting to know that Başa and Dilek assessed the risk of perforation of the MC by implant drill using density and thickness parameters [57]. They investigated whether the resistance of the bone surrounding the MC had sufficient density and thickness to avoid perforation by implant drills. Study of the computed tomography (CT) images of 99 patients, whose age ranged between 20 and 79 years, showed that overall, average bone thickness in the premolar and molar regions was $0.87 \pm 0.18$ and $0.86 \pm 0.18 \mathrm{~mm}$, respectively, whereas the bone density in the premolar and molar regions was $649.18 \pm 241.42$ and $584.44 \pm$ 222.73 Hounsfield units $(\mathrm{HU})$, respectively $(\mathrm{P}<0.001)$. It was concluded that the average density and thickness of the bone that surrounds the MC was not sufficient to resist the implant drill. The risk of IAN injury can be avoided by accurately determine the bone mass around the canal and avoidance of use excessive force when approaching the canal [57].

Another cause of injury to the IAN is the displacement of 
an implant into canal. For example, in the posterior mandible, cancellous bone is more abundant and has bigger intratrabecular spaces but less dense than in anterior mandible $[58,59]$. In some cases with low density bone, the twist drills may drop into trabecular bone spaces during preparation thus leads to the displacement of the implants deeper than planned [60]. CT-based intraoperative navigation has been recommended to minimize the nerve damage [61]. One hundred test drillings were carried out on 10 standardized acrylic lower jaw models with the aid of navigation system [61]. An average drilling depth of $6.23 \mathrm{~mm}$ and a mean distance to the $\mathrm{MC}$ of $0.14 \mathrm{~mm}(\mathrm{~s}=0.05)$ was found. Eleven cases showed perforation of the upper border of the canal. The average penetration of the MC was $0.19 \mathrm{~mm}$. In contrast, Burstein et al. recommended using intraoperative periapical radiographs during the drilling sequence as an inexpensive and reliable tool, allowing the operator to confidently adjust the direction and depth of the implant during the placement [62]. Most importantly, it helps to avoid the risk of injury to the IAN especially in those cases with limited vertical alveolar bone. No incidents of postoperative paresthesia noted in 21 implants that authors placed [62]. Using the drills with guards is another option to fully control of the drilling depth $[\underline{54}, \underline{57}]$.

One of possible intraoperative complications is direct chemical trauma - alkalinic nerve injuries from irrigation of the implant bed during preparation with sodium hypochlorite. This solution has not been recommended in practice and should be avoided [63].

Sensory IAN injuries evoked by partial perforation of the MC during the drilling are caused by indirect postoperative trauma - secondary ischemia of the IAN by haemorrhage into the canal and scaring process, rather than direct mechanical trauma by the drill or implant itself (Figure 1C) [ $[\underline{63}, \underline{64}]$.

Thermal stimuli can evoke peri-implant bone necrosis and postoperative secondary IAN damage. Nerve tissue is thought to be more sensitive to thermal insult than bone and it may lead to primary IAN injury (Figures 1D and E) [65]. The increase in temperature, produced by excessive drill speed produces necrosis, fibrosis, osteolytic degeneration and an increase in osteoclastic activity. The thickness of the necrotic area is directly proportional to the amount of heat generated during the surgery [66]. Since Eriksson and Albrektsson proposed heating of the $47{ }^{\circ} \mathrm{C}$ as a maximum limit that bone can withstand without necrosis $[\underline{67}, \underline{68}]$ since the heat generated at $47{ }^{\circ} \mathrm{C}$ for five minutes could produce $20 \%$ of bone resorption [67]. However, controversy remains about the use of external or internal irrigation for cooling. Nonetheless, it is reported no differences between the two irrigation systems in a recent study [69].

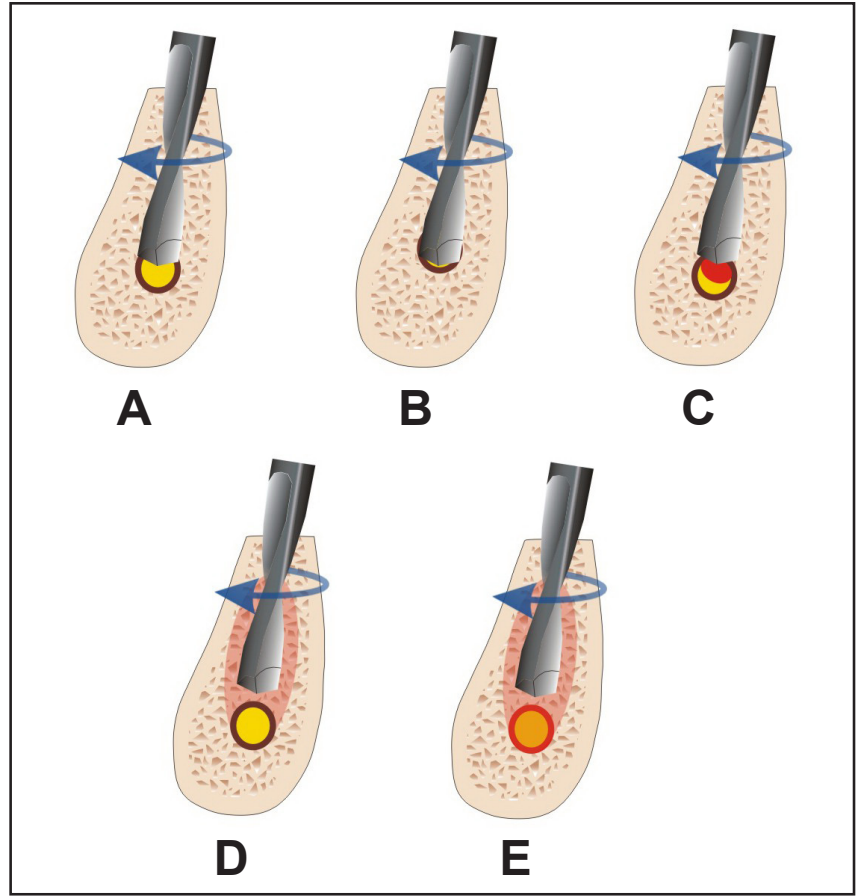

Figure 1. A = partial implant drill intrusion into mandibular canal can cause direct mechanical IAN trauma - encroach, or laceration and primary ischemia.

$\mathrm{B}=$ full implant drill intrusion into mandibular canal can cause direct IAN transection and primary ischemia.

$\mathrm{C}=$ partial implant drill intrusion into mandibular canal can cause indirect trauma due to hematoma and secondary ischemia.

$\mathrm{D}=$ thermal stimuli can evoke periimplant bone necrosis and postoperative secondary IAN damage.

$\mathrm{E}=$ thermal stimuli can evoke primary IAN damage.

\section{Inferior alveolar nerve injury by dental implant}

Sensory IAN injuries made by dental implant may be caused by direct intraoperative (mechanical) and indirect postoperative trauma (ischemia) or periimplant infection [55]. Direct mechanical injury i.e. encroach, transection, or laceration of the nerve is related to implant intrusion into the MC (Figures 2A and B). After direct trauma, when the implant is placed through the bony canal, the nerve ending may get retrograde degeneration in most of the cases, because the nerve running in the canal is a terminal ending of the nerve and the size is quite small [무]. Otherwise partial implant intrusion into MC can evoke IAN injury due to compression and secondary ischemia of corresponding neurovascular bundle $[\underline{54}, \underline{71}]$. For example, immediate implantation following tooth extraction can sometimes cause implant intrusion into MC. Efforts by the surgeon to achieve primary stability can lead to unintentional apical extension and nerve injury. Re-measurement the amount of available bone after tooth extraction is recommended especially in those cases of nerve proximity since a few millimetres of the crestal bone might be lost during the extraction [15]. 


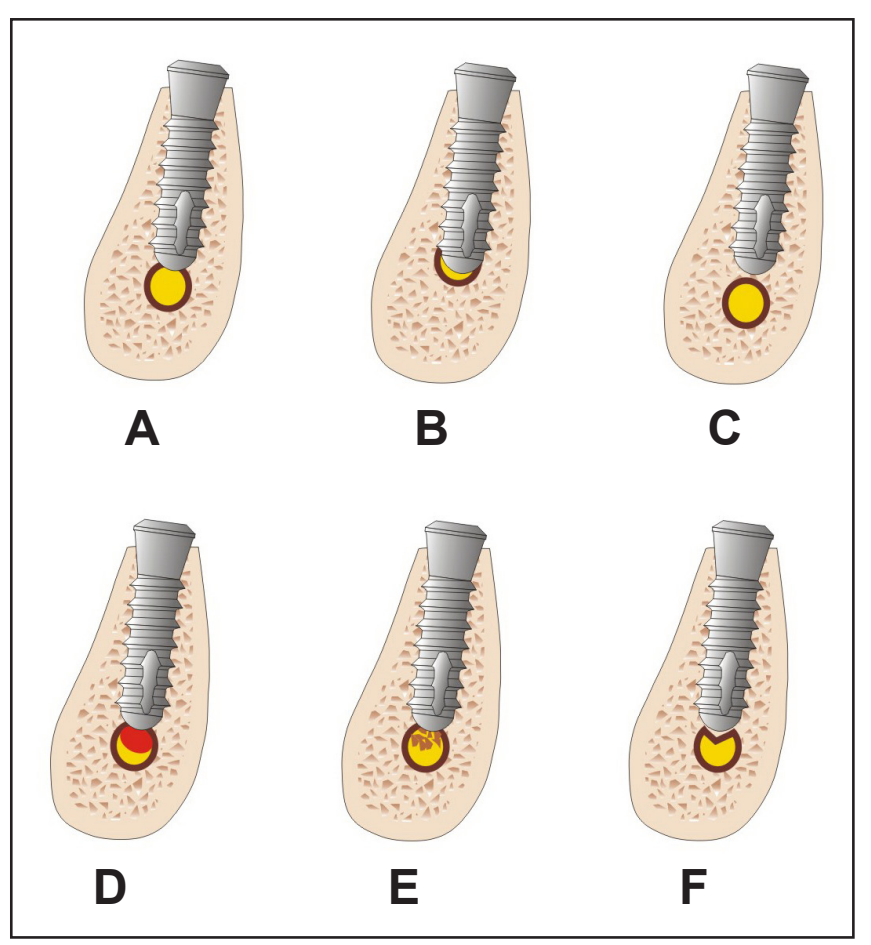

Figure 2. $\mathrm{A}=$ partial implant intrusion into mandibular canal can cause direct mechanical IAN trauma - encroach, or laceration and primary ischemia.

$\mathrm{B}=$ full implant intrusion into mandibular canal can cause direct IAN transection, and/or compression and primary ischemia.

$\mathrm{C}=$ dental implant is too close to the mandibular canal, it can cause IAN compression.

$\mathrm{D}=$ partial implant intrusion into mandibular canal can cause indirect trauma due to hematoma and secondary ischemia.

$\mathrm{E}=$ partial implant intrusion into mandibular canal can cause indirect trauma due to bone debris and secondary ischemia.

$\mathrm{F}=$ "cracking" of the IAN canal roof by its close proximity to preparation of the implant bed. It can cause compression and primary ischemia.

Limited evidence exists with regard to the proper distance between the implant and the MC to ensure the nerve's integrity and physiologic activity. The proper distance should come from evaluation of clinical data as well as from biomechanical analyses $[\underline{72}, 73]$. Sammartino et al. created a numeric mandibular model based on the boundary element method to simulate a mandibular segment containing a threaded fixture so that the pressure on the trigeminal nerve, as induced by the occlusal loads, could be assessed [72]. They found that the nerve pressure increased rapidly with a bone density decrease. A low mandibular cortical bone density caused a major nerve pressure increase. In conclusion, they suggested a distance of $1.5 \mathrm{~mm}$ to prevent implant damage to the underlying IAN when biomechanical loading was taken into consideration (Figure 2C).

The IAN may be affected by perforation of the MC during drilling, or positioning the implant close to the canal and the subsequent formation of an adjacent hematoma that presses against the nerve (Figure 2D) [64]. Khawaja and Renton [63] indicated that "cracking" of the IAN canal roof by its close proximity to preparation of the implant bed (millimetres) may cause haemorrhage into the canal or deposition of debris which may compress and cause ischemia of the nerve (Figures 2E and F). Furthermore, this constrictive effect on the nerve may persist if the implant is left in situ or even if the implant is "backed-up" or a shorter implant is placed [63].

Sensory IAN injury can be evoked by postoperative periimplant infection. Implant periapical lesions are infectious-inflammatory alterations surrounding an implant apex, and can be caused by a number of situations - including contamination at instrumentation, overheating of bone, and the prior existence of bone pathology [74]. Elian et al. reported a patient with typical signs of peri-implantitis and IAN injury [75]. The implant was placed in proximity to the mental foramen and possibly had traumatized the mental nerve since the patient reported an altered sensation in his left side. After removal of the implant, a significant diminishing of the paresthesia had occurred, described by the patient as a $40 \%$ improvement [75].

Sensory disturbances might also be related to chronic stimulation. If the implant is situated aside of or on top of the nerve, then the nerve can be stimulated recurrently each time when biting or chewing. It is likely that such chronic stimulation may therefore end up as chronic neuropathy [ㄷ].

\section{Inferior alveolar nerve injury using wrong operation technique}

Injury of the final part of the IAN - mental nerve can occur in those cases when an extreme degree of alveolar process resorption exists. In such cases, the mental foramen was found in the surface of alveolar bone and directly under the gums [77-79]. To avoid direct injury with scalpel, the initial incision should be made more lingually and a full-thickness flap is elevated until the mental foramen is identified [이. In addition, flap reflection or retraction, suturing, soft tissue swelling and pressure on the mental nerve area can also cause injury to that nerve, resulting in altered sensation after surgery $[\underline{6}, 9,34, \underline{31}, \underline{82}]$.

\section{Related risk factors}

Possible related risk factors can be classified as general risk factors, intraoperative and postoperative.

\section{General risk factors}

All patients must have realistic expectations and also be warned of IAN injury. The assessment of risk must be 
undertaken in order to appropriately advise the patient with regard to alternative treatment plans and include this possibility in the consent forms [55]. Patient must sign informed consent form prior to implant surgery [55]. It is important for clinicians to perform a neurosensory examination of mandibular nerve function before placing the implant to determine whether there is pre-existing altered sensation. Great care must be taken when selecting possible sites for implant placement [ㄷ]. The anatomical and radiological risk factors related to mandibular vital structures have been discussed thoroughly in literature [18-20].

It is well documented for all types of nerve injuries that both factors - females and increasing age are at the greater risk of neurosensory deficits. In older individuals, cell body regeneration has been shown to be slower and less dramatic than in younger individuals $[\underline{27}, \underline{85}, \underline{89}]$.

\section{Intraoperative risk factors}

It is important to know risk factors which can be an indicator of possible IAN damage. For example, in case of protrusion through the buccal plate or perforation of the MC and IAN direct mechanical injury by implant drill or injection needle a "sudden give" or an "electric shock" type feeling appears for most of the patients [63].

If there is an inferior alveolar arterial or venous bleed it may be advisable not to place the implant and to wait two to three days to ensure no nerve damage has occurred and then place the implant in granulation tissue. However, there is no evidence to support this practice yet [주] .

Slippage of the drill, implant placement deeper than planned or bigger diameter implant placement can be also characterised as intraoperative risk factors [15].

\section{Postoperative risk factors}

The IAN is contained within a bony canal which predisposes it to compression and as a result ischemic type injury. Persistence of any peripheral sensory nerve injury depends on the severity of the injury [83-85], the time elapsed since the injury [6] and the proximity of injury to the cell body (the more proximal lesions the worst the prognosis) [87]. The more proximal to the nerve injury site, the higher the risk of trigeminal ganglion cell damage. This often leads to the retrograde differentiation effect on the central nervous system [87]. Less traumatic injuries often are associated with hyperesthesias. In contrast, more severe injuries are initially anaesthetic lesions with poor orofacial function and associated referred, radiating forms of paresthesia.
Although, these may not be painful initially, they may eventually lead to dysfunctional chronic neuroma formation $[\underline{83}, \underline{84}]$.

It has been demonstrated that the compression of peripheral nerve over 6 hours can evoke nerve fibres atrophy [8]. Three months after the IAN injury, permanent central and peripheral changes occur within the nervous system subsequent to injury, that are unlikely to respond to surgical treatment intervention [90]. If the injury persists beyond 6 months it is deemed to be permanent [86].

\section{Classifications of inferior alveolar nerve injury}

In 1943, Seddon described a triple classification of mechanical nerve injuries to characterize the morphophysiologic types of mechanical nerve injuries [91]. Seddon's classification (neuropraxia, axonotmesis and neurotmesis) is based on the time course and completeness of sensory recovery. LaBanc discussed this classification in case of trigeminal nerve injury [92]. Neuropraxia is characterized by a conduction block, the rapid and virtually complete return of sensation or function, and no degeneration of the axon. It may be the result of nerve trunk manipulation, traction, or compression of a nerve. Trauma of sufficient magnitude to injure the endoneurial capillaries causes intrafascicular oedema, resulting in a conduction block. Normal sensation or function returns within 1 to 2 days following the resolution of intrafascicular oedema, generally within 1 week following the nerve injury. Pressure on the nerve may also result in segmental demyelination or mechanical disruption of the myelin sheaths. In this case, sensory and functional recoveries are complete within 1 to 2 months. The response to this type of injury is paresthesia [92].

An axonotmesis is characterized by axonal injury with subsequent degeneration or regeneration. Traction and compression are the usual mechanisms of this type of injury. These may cause severe ischemia, intrafascicular oedema, or demyelination. Even though the axons are damaged, there is no disruption of the endoneurial sheath, perineurium, or epineurium. Complete recovery can occur in 2 to 4 months, but improvement leading to complete recovery may take up as long as 12 months. It is important to know that within 2 to 4 months following injury there are signs of sensation or function which continue to improve over the next 8 to 10 months. The psychophysical response to an axonotmesis is an initial anaesthesia followed by a paresthesia as recovery begins [92].

A neurotmesis is characterized by severe disruption of the connective tissue components of the nerve trunk with compromised sensory and functional recovery. 
The aetiology of nerve injury is traction, compression, injection injury, chemical injury or in a complete disruption of the nerve trunk laceration and avulsion. The psychophysical response to these injuries is the immediate anaesthesia. It will then follow-up by paresthesia or possibly neuropathic responses such as allodynia, hyperpathia, hyperalgesia, or chronic pain. With this type of nerve injury there is a poor prognosis for recovery. For example, sensory and functional recovery is never complete and has a high probability of development of a central neuroma [92].

Sunderland, in 1951, classified nerve injury based on the degree of tissue injury that emphasizes the importance of each structural component of the nerve trunk [93]. Under his system, first-degree injury, of which there are 3 types, is similar to Seddon's neuropraxia (Table 2). Type 1 results from nerve trunk manipulation, mild traction, or mild compression and is thought to reflect transient ischemia. If blood flow is restored, nerve function usually returns to normal; with more prolonged ischemia, permanent injury and anaesthesia may occur. Type 2 results from more prominent traction or compression that produces intrafascicular oedema, decreased blood flow, and a conduction block. Recovery is variable. Type 3 injuries result from the severe nerve traction or compression causing segmental mechanical disruption of the myelin sheaths and demyelination. Recovery is delayed and sensory loss may be permanent [94].

Second-, third-, and fourth-degree injuries correspond with Seddon's classification of axonotmesis. The afferent or efferent fibres are damaged, but endoneurium, perineurium, and epineurium remain intact. Surgical decompression may be necessary, and recovery requires axonal regeneration. Thirddegree injury occurs when the intrafascicular tissue components (axons and endoneurium) are damaged. If there is poor clinical recovery, surgical reconstruction may be needed. Fourth-degree injury implies fascicular disruption: all components are damaged and only the epineurium remains intact. The prognosis is poor, and surgical reconstruction often indicated [92]. Fifthdegree injury implies nerve transection. Surgical approximation and coadaptation may be required [92]. Rood correlated histological findings with clinical data and found that the clinical sign and symptom is the best indicator for reflection of the degree of initial injury [95]. If there is complete numbness that improves over time, this is indicative of first- or second-degree injury according to the Sunderland classification. The presence of complete numbness initially does not indicate nerve severance [96].

Jalbout and Tabourian classified three categories of neurosensory alterations during the implant placement [97]. These include: 1) neuropraxia (mild injury in which feeling is reversed within 4 weeks postsurgery); 2) axonotmesis (nerve compression, structure remains intact, and signs of feeling return 5 to 11 weeks postsurgery and continue to improve in the next 10 months); and 3) neurotmesis (disruption of the nerve with poor prognosis for return of feeling) [97]. Many nerve injuries that do not fit neatly into this classification and are more complicated. For example, a rotating bur may not only partially divide but also stretch the nerve. Inflammation around the nerve, caused by infection or foreign bodies, may also alter neural function and increase the pain experienced [98].

\section{Clinical symptoms in case of inferior alveolar nerve injury}

IAN sensory disturbances should be diagnosed based on patients' complaints and clinical symptoms. IAN injury can cause paresthesia to complete numbness and/or pain [15] in the region of the skin of the mental area, the lower lip, mucous membranes, and the gingiva as far posteriorly as the second premolar $[99,100]$. Furthermore this commonly interferes with speech,

Table 2. Neurosensory impairment classification according to Sunderland [93] and Seddon [91]

\begin{tabular}{|c|c|c|c|c|}
\hline Sunderland & Seddon & Injury & Neurosensory impairment & Recovery Potential \\
\hline \multirow{2}{*}{ I } & \multirow{2}{*}{ Neuropraxia } & Intrafascicular oedema, conduction block & Neuritis, paresthesia & Full (1day to 1 week) \\
\hline & & Possible segmental demyelination & Neuritis, paresthesia & Full (1 to 2 months) \\
\hline II & \multirow{3}{*}{ Axonotmesis } & Axon severed, endoneurial tube intact & $\begin{array}{l}\text { Paresthesia, episodic } \\
\text { dysesthesia }\end{array}$ & Full (2 to 4 months) \\
\hline III & & Endoneurial tube torn & Paresthesia, dysesthesia & Slow, incomplete (12 months) \\
\hline IV & & Only epineurium intact & $\begin{array}{l}\text { Hypoesthesia, dysesthesia, } \\
\text { neuroma formation }\end{array}$ & Neuroma-in-continuity \\
\hline $\mathbf{V}$ & \multirow[t]{2}{*}{ Neurotmesis } & Loss of Continuity & $\begin{array}{l}\text { Anaesthetic, intractable } \\
\text { pain, neuroma formation }\end{array}$ & None \\
\hline VI & & Combination of above & Combination of above & Unpredictable \\
\hline
\end{tabular}


eating, kissing, make-up application, shaving and drinking $[\underline{8}]$.

These altered sensations can be categorized as anaesthesias, paresthesias or dysesthesias $[28, \underline{31}$, $\underline{33}, \underline{35}, \underline{40}, \underline{92}, \underline{101]}$. Anaesthesias represent the total absence of sensation, including the pain. Paresthesias (formication) encompass a broader category of abnormal sensations, such as "pins and needles," which may not be unpleasant. There are also hypoesthesias who represents diminished sensitivity to stimulation, excluding special senses and hyperesthesia - a condition that involves an abnormal increase in sensitivity to stimuli of the senses. Dysesthesias represent a form of spontaneous or mechanically evoked painful neuropathy. This category can encompass hyperalgesia (a rapid and exaggerated painful response to non painful stimuli), hyperpathia (a delayed and prolonged pain response), sympathetic mediated pain (pain that is worsened by increasing sympathetic tone) and anaesthesia dolorosa (pain in an area of anaesthesia), allodynia (pain due to a stimulus that does not normally provoke pain) $[92,101]$.

The Association for the Study of Pain has standardized a nomenclature system that defines the most frequently used neurosensory descriptive terms [102] (Table 3).

\section{Methods for function assessment of the inferior alveolar nerve}

Clinicians should document any unusual response (such as "sudden give" or an "electric shock" type feelings) during the administration of local anaesthetic or during the surgery $[\underline{56}, \underline{63}]$. In every case, after dental implant operation in distal mandible, each patient should be contacted after the local anaesthetic has worn off. A simple phone call 6 hours postsurgery will enable the surgeon to ascertain from the patient whether the analgesic effects of the local analgesia have worn off and if neuropathy is present [ $\underline{63}]$.

If a nerve injury is suspected, the clinician should Clinical sensory testing is still most popular perform a basic neurosensory examination of the neuropathic area and ascertain whether the patient experiences pain, altered sensation or numbness and document the findings within the day of surgery (when the effects of anaesthetic should have worn off) $[\underline{56}, \underline{63}]$. The clinician should map any area of neurosensory deficit and photograph it to compare with future photographs. The purpose of the sensory diagnostic evaluation is to document whether or not a neurosensory disturbance exists, to quantitate the disturbance, to monitor sensory recovery, to determine whether or not microreconstructive surgery may be indicated, and to monitor sensory recovery following microreconstructive surgery $[\underline{86}, \underline{103}, \underline{104}]$.

The methods of evaluation of the neurosensory function of the lower lip and chin has varied widely, from pure patient questioning to sophisticated, high-technological examination modalities [105]. The most sensitive indicator of a sensory abnormality is the patient's own subjective report, as minor sensory disturbances may not be detected by testing [106]. Otherwise, many authors have highlighted the particular discrepancy between these subjective quantitative methods (what pressure? how many millimetres?) and the patient's subjective qualitative reports (pain, altered sensation or disability), particularly as the patient's complaints are the driving-force behind the patient seeking further advice or treatment for their injury [81]. Although there have been numerous studies evaluating trigeminal neurosensory disturbance due to maxillofacial surgery, there seems to be no consensus as to the ideal choice of methods with which to measure such impairments.

Currently, the diagnosis of sensory disturbances of the IAN is based on subjective clinical sensory testing and objective sensory tests (Table 4).

\section{Subjective clinical sensory testing}

Table 3. Description of neurosensory impairment deficits [102]

\begin{tabular}{ll}
\hline Anaesthesia & Total loss of feeling or sensation \\
Dysesthesia & Abnormal sensation which is unpleasant \\
Allodynia & Pain due to a stimulus that does not normally provoke pain \\
Hyperpathia & Abnormally painful reaction to a stimulus \\
Causalgia & Persistent burning pain \\
Anaesthetic dolorosa & Pain in an area that is anaesthetic \\
Paresthesia & Abnormal sensation that is not unpleasant \\
Hypoesthesia & Decreased sensitivity to stimulation \\
Hyperesthesia & Increased sensitivity to stimulation \\
Hypoalgesia & Decreased response to a stimulus that is normally painful \\
Hyperalgesia & Increased response to a stimulus that is normally painful \\
Synesthesia & Sensation felt in an area when another area is stimulated \\
\hline
\end{tabular}


Table 4. Subjective clinical sensory testing methods description and IAN structures assessed [103, 105-116]

\begin{tabular}{lll}
\hline \multicolumn{1}{c}{ Name of test } & \multicolumn{1}{c}{ Description } & Structure assessed \\
\hline \multicolumn{1}{c}{ Mechanoceptive } & & $\begin{array}{l}\text { Myelinated afferent A-beta } \\
\text { axons }\end{array}$ \\
\hline Static light touch detection & $\begin{array}{l}\text { Patient is asked to tell when he/she feels light touch on the face and to } \\
\text { point to the exact location }\end{array}$ & $\begin{array}{l}\text { Large A-alpha and A-beta } \\
\text { myelinated axons }\end{array}$ \\
\hline $\begin{array}{l}\text { Brush directional } \\
\text { discrimination }\end{array}$ & Patient is asked to tell when he/she feels the brush and to determine \\
\hline $\begin{array}{l}\text { Two-point discrimination } \\
\text { (sharp) }\end{array}$ & $\begin{array}{l}\text { Patient is asked to determine single and 2 points of touch. The examiner } \\
\text { uses any } 2 \text { sharp instruments by which the patient can change the } \\
\text { distance between them }\end{array}$ & $\begin{array}{l}\text { Small myelinated A-delta } \\
\text { and unmyelinated C-afferent } \\
\text { fibres }\end{array}$ \\
\hline $\begin{array}{l}\text { Two-point discrimination } \\
\text { (blunt) }\end{array}$ & $\begin{array}{l}\text { Patient is asked to determine single and 2 points of touch. The examiner } \\
\text { uses any } 2 \text { blunt instruments by which the patient can change the } \\
\text { distance between them }\end{array}$ & $\begin{array}{l}\text { Larger myelinated A-alpha } \\
\text { afferent fibres }\end{array}$ \\
\hline Nociceptive & & $\begin{array}{l}\text { Free nerve endings and the } \\
\text { small A-delta and C-fibres }\end{array}$ \\
\hline $\begin{array}{l}\text { Pin pressure nociception } \\
\text { Thermal discrimination } \\
\text { (warm) }\end{array}$ & Patient is asked to determine the feeling of a pin prick \\
\hline $\begin{array}{l}\text { Thermal discrimination } \\
\text { (cold) }\end{array}$ & Patient is asked if he/she feels heat & A-delta fibres \\
\hline
\end{tabular}

in the daily practice. Clinical neurosensory testing can be divided into two basic categories, mechanoceptive and nociceptive, based upon the specific receptors stimulated through cutaneous contact. Mechanoceptive tests include static light touch, two-point discrimination and brush stroke direction. Pin tactile discrimination and thermal discrimination are nociceptive tests. Each test assesses specific categories of the receptors and axons [103].

\section{Mechanoceptive tests}

Static light touch detection

The static light touch detection assesses the integrity of the cells, which are innervated by myelinated afferent A-beta axons. These receptors adapt slowly, and their putative sensory modality is pressure. The large myelinated A-beta fibres are highly susceptible to compression injury. The patient closes his eyes and says "yes" whenever he feels a light touch to the face and points to the exact spot where he felt the touch.

\section{Brush directional discrimination}

This is a test of proprioception and assesses the integrity of the large A-alpha and A-beta myelinated axons. The sensory modalities for these receptors are vibration, touch and flutter. The patient tells if any sensation is detected and in which direction the filament or brush moved.
Two-point discrimination (2-P)

This is a test which assesses the quantity and density of functional sensory receptors and afferent fibres. If sharp points are used, the small myelinated A-delta and unmyelinated $\mathrm{C}$-afferent fibres are assessed. If blunt points are used, the larger myelinated A-alpha afferent fibres are assessed. 2-P is measured with any instrument with which the distance between two points can be altered. With the patient's eyes closed the test is initiated with the points essentially touching so that the patient is able to discriminate only one point. The normal values vary a lot, the average value being around $5 \mathrm{~mm}[\underline{107]}$.

\section{Nociceptive tests}

Pin pressure nociception.

This test assesses the free nerve endings and the small A-delta and C-fibres that innervate the free nerve endings responsible for nociception. For this test the most common instrument is algesimeter. This instrument is made from a needle and an orthodontic strain gauge. The sharp point of the needle is used to test nociception and the blunt end to test for pressure detection. The magnitude of force necessary to feel the sharpness of the unaffected area is recorded as the nociceptive threshold for the affected area. The normal values also vary a lot in this test, but $15 \mathrm{gm}$ is considered to be an adequate force to elicit this response [108]. An exaggerated response to 
pin pressure relative to an unaffected area is defined as hyperalgesia. A reduced response (touch) relative to an unaffected area is hypoalgesia. No response is defined as anaesthesia.

\section{Thermal discrimination}

Thermal discrimination is a useful test of sensation but is not essential. It assesses also the integrity of small myelinated and unmyelinated fibres similar to those tested with pin pressure nociception. Warmth sensation is attributed to A-delta fibres and cold to C-fibres. Different instruments are available for thermal testing, including thermodes and Minnesota Thermal Disks, as well as ice, ethyl chloride sprays, acetone, and water.

\section{Other subjective clinical sensory tests \\ Diagnostic nerve block}

Diagnostic nerve block is one part of the diagnostic evaluation when pain is a symptom. The purpose of this test is to aid in determining the mechanism of pain, locating the source of the pain, identifying the pain pathway, and determining the prognosis for decreasing or eliminating the pain. If the block relieves the pain, then microreconstructive surgery usually offers a favourable prognosis.

\section{Objective sensory tests}

\section{Trigeminal somatosensory evoked potentials}

Trigeminal somatosensory evoked potentials is an electrophysiologic method of evaluating the trigeminal pathway. The potential changes of cerebral origin will be detected on the scalp in human subjects after electrical stimulation of peripheral nerves [109]. The central nervous system response is recorded by signal averaging the electro encephalogram. Stimulating electrodes are applied to the cutaneous region to be tested and recording electrodes are applied to the scalp. The responses are analysed and plotted by a signal averaging system. The resultant response plot is analyzed for the peak latencies and amplitudes. However, contemporary devices have many disadvantages including contamination with undesirable myographs and artefacts in a record, recording difficulties, and varying clinical techniques $[\underline{105}, \underline{110}]$

\section{Orthodromic sensory nerve action potentials}

Another method to monitor the function of the IAN is orthodromic sensory nerve action potential recording $[111,112]$. It is used routinely in combination with electromyography to assess peripheral nerve function.
The recording electrode is inserted beneath the zygomatic arch in front of the temporomandibular joint, as near to the mandibular branch of the trigeminal nerve as possible. The stimulating needle tips are inserted at the mental foramen as close to the nerve as possible. Onset latencies of the sensory nerve action potentials and the amplitudes are recorded. Furthermore, the nerve conduction velocity of the IAN is calculated [103]. Colin investigated conduction velocity data for the uninjured human IAN, and determined if there are differences in the inferior alveolar conduction velocities for either side or for gender [113]. The mean maximal conduction velocity was $65.0 \mathrm{~m} / \mathrm{s}$, with no differences shown for right or left sides or for gender. There was a slight decrement in conduction velocity with age. It was concluded that conduction velocity testing of the IAN in health, injury, and after repair is feasible and practical.

\section{Blink reflex}

Since the introduction of a method for electrically elicited blink reflex by Kugelberg, the physiology and anatomy of this cranial reflex has been under extensive study [114]. Jääskeläinen and co-workers published the first study concerning the blink reflex with stimulation of the mental nerve [115]. In this technique, the active recording electrodes are placed on the outer border eyelids on the orbicularis oculi muscles on the both sides. Reference electrodes are fixed on both sides of the nose. A ground electrode is wrapped around the arm. The blink reflexes are elicited by electrical stimulation with a small bipolar surface electrode with $10 \mathrm{~mm}$ interelectrode distance. The stimulating cathode is placed on the vermilion border of the lower lip midway between the midline and the corner of the mouth, the anode lay below on each side. Stimulation of the mental nerve is made with a larger bipolar surface electrode between the stimulating cathode and the anode. The blink reflex responses are recorded simultaneously on both sides. Blink reflex proved to be a sensitive test in detecting IAN lesions within 2 to 3 months from injury [116].

\section{Patient with dental implant placement in mandible and inferior alveolar nerve injury management}

Table 5 shows nine stages to prevent IAN injury as well as management of nerve injury if injury did occur in patients with dental implant treatment. These are guidelines that cover all phases of treatment. Below is a detailed description of these steps.

\section{Stage I - the record of general risk factors}

All patients must have realistic expectations and also be warned of the IAN injury. They must sign 
Table 5. Guidelines to prevent IAN injury as well as management of nerve injury if injury did occur in patients with dental implant treatment

\begin{tabular}{|c|c|}
\hline ages & IAN injury management procedures \\
\hline $\begin{array}{l}\text { I Stage } \\
\text { General risk factors } \\
\text { identification }\end{array}$ & $\begin{array}{l}\text { Record of general risk factors. Patients must sign informed consent form. Clinicians must perform a } \\
\text { neurosensory examination of mandibular nerve function before placing the implant. It should be taken on } \\
\text { account the age and gender of the patient, anatomical and radiological risk factors in operation planning. }\end{array}$ \\
\hline $\begin{array}{l}\text { II Stage } \\
\text { Intraoperative } \\
\text { factors identifi }\end{array}$ & Record of intraoperative risk factors. If present, patient is immediately assigned to IAN injury patient group. \\
\hline $\begin{array}{l}\text { III Stage } \\
\text { Patient complaints } \\
\text { identification }\end{array}$ & $\begin{array}{l}\text { Contact with patient after local anaesthesia wears off. If patient has any complaints related with } \\
\text { corresponding IAN sensory disturbances, patient is immediately assigned to IAN injury patient group. }\end{array}$ \\
\hline $\begin{array}{l}\text { IV Stage } \\
\text { Postoperative } \\
\text { examination, } \\
\text { postoperative risk } \\
\text { factors evaluation and } \\
\text { diagnosis statement }\end{array}$ & $\begin{array}{l}\text { Neurosensory examination for assessment of the severity of the lesion. Neurosensory deficit area mapping } \\
\text { and photographing it to compare with future photographs. } \\
\text { Radiographic examination for localization of the lesion documentation and confirmation whether INA injury } \\
\text { has been caused by the implant. } \\
\text { Postoperative risk factors evaluation it is important to evaluate severity of the injury, the time elapsed since } \\
\text { the injury and the proximity of the injury to the cell body. } \\
\text { Diagnosis statement based on patient complaints, IAN neurosensory and radiographic examination results. }\end{array}$ \\
\hline & $\begin{array}{l}\text { Psychological treatment: immediate information, explanation, support. } \\
\text { Physiological treatment: implant removal when implant is in any contact with mandibular canal or there are } \\
\text { symptoms of IAN sensory deficit. } \\
\text { Cleaning of any irritant (bone debris, hematoma) in close approximation to the neurovascular bundle if possible. } \\
\text { Medicament treatment: three weeks course of steroids and NSAIDs. } \\
\text { - } \quad \text { Topically } 1 \mathrm{ml} \text { of intravenous form of dexamethasone ( } 4 \mathrm{mg} / \mathrm{ml}) \text {. } \\
\text { - } \quad \text { Oral dexamethasone } 4 \mathrm{mg} 2 \text { tablets AM for } 3 \text { days and } 1 \text { tablet AM for next } 3 \text { days or oral prednisolone } \\
\quad 1 \mathrm{mg} \text { per kg per day (maximum } 80 \mathrm{mg} \text { ). } \\
\quad \text { Alternatively or as an adjunct high dose of NSAIDs medication (such as ibuprofen [ } 800 \text { milligrams] } \\
\text { three times per day). } \\
\text { Cryotherapy: the paraneural tissues should have ice applied intensely for the first } 24 \text { hours postoperatively } \\
\text { and then episodically for the first week. } \\
\text { Additional treatment: } \\
\text { - pharmacologic agents include antidepressants, anticonvulsants, antisympathetic agents, and topical } \\
\text { medications. } \\
\text { physiologic therapies can be indicated and prescribed by a nerve specialist. This treatment include } \\
\text { transcutaneous electric nerve stimulation, acupuncture, and low level laser therapy. }\end{array}$ \\
\hline $\begin{array}{l}\text { VI Stage } \\
1 \text { week postoperative } \\
\text { examination }\end{array}$ & $\begin{array}{l}\text { Neurosensory examination: for monitoring of the IAN sensory function recovery. Neurosensory deficit area } \\
\text { mapping and photographing it to compare with previous photographs. If paresthesia is present, neurosensory } \\
\text { examination should be continued every week for } 3 \text { weeks and later every } 2-3 \text { weeks for } 12 \text { weeks. } \\
\text { Clinical examination: for assessment of postoperative area healing, hematoma, oedema reduction. }\end{array}$ \\
\hline $\begin{array}{l}\text { VII Stage } \\
1 \text { week postoperative } \\
\text { treatment }\end{array}$ & $\begin{array}{l}\text { Psychological treatment: patient should feel psychological support. } \\
\text { Medicamental treatment: oral NSAIDs medication (such as ibuprofen [ } 800 \text { milligrams] three times per day) } \\
\text { should be continued for } 3 \text { weeks. } \\
\text { If necessary additional } 3 \text { weeks of NSAIDs may be prescribed during } 12 \text { weeks postoperation. } \\
\text { Microneurosurgical treatment: if IAN transection was observed intraoperatively or if there is dysesthesia or } \\
\text { complete anaesthesia in innervation zone, referral to a microneurosurgeon is indicated. } \\
\text { Aditional treatment: pharmacologic, physiologic therapies can be prescribed if indicated. }\end{array}$ \\
\hline $\begin{array}{l}\text { VIII Stage } \\
12 \text { weeks postoperative } \\
\text { examination }\end{array}$ & $\begin{array}{l}\text { Neurosensory examination: for monitoring of the IAN sensory function recovery. Neurosensory deficit area } \\
\text { mapping and photographing it to compare with previous photographs. }\end{array}$ \\
\hline $\begin{array}{l}\text { IX Stage } \\
12 \text { weeks postoperative } \\
\text { treatment }\end{array}$ & $\begin{array}{l}\text { Medicament treatment: can be prescribed according to indications. } \\
\text { Microneurosurgical treatment: should be prescribed if there are no signs of improvement. } \\
\text { Aditional treatment: pharmacologic, physiologic therapies can be prescribed if indicated. }\end{array}$ \\
\hline
\end{tabular}


informed consent form [55]. Clinicians must perform a neurosensory examination of mandibular nerve function before placing the implant to determine whether there is pre-existing altered sensation [56]. It should be taken on account the age and gender of the patient because it is well documented for all types of the nerve injuries that both factors - females and increasing age are at greater risk of neurosensory deficits. In older individuals, cell body regeneration has been shown to be slower and less dramatic than in younger individuals $[27,85,90]$.

\section{Stage II - the record of intraoperative risk factors}

Taking on account that pain ("sudden give" or an "electric shock") and arterial or venous bleed induced during local anaesthesia or bone preparation is not always persisting during the IAN injury, all patients should be contacted after local anaesthesia wears off [33]. Since studies have demonstrated that an "electric shock" sensation is not indicative of the permanent nerve injury, but damage to the nerve may occur even with a small needle contact $[28,33]$.

\section{Stage III - patient complaints identification}

If a nerve injury is suspected, the clinician should record the patient's complains related to altered sensation and perform a thorough neurosensory examination documenting the results the day after surgery, but not later then 36 hours (when the effects of anaesthetic should have worn off) [63]. If patient has any complaints related with corresponding IAN sensory disturbances, patient is immediately assigned to IAN injury patient group.

\section{Stage IV - postoperative examination and diagnosis statement}

As mentioned earlier, nerve injury can occur for many reasons. For appropriate management, the exact cause of injury, accurate localization of the lesion and assessment of severity of the lesion are very important in selecting the appropriate management strategies [16]. The clinician should map any area of neurosensory deficit and photograph it to compare with future photographs [드] or refer to specialist for proper timely management. Radiographic examination is essential for localization of the lesion documentation and confirmation whether INA injury has been caused by the implant. Computed tomographic (CT or CBCT) images are more consistent with direct measurements in comparison with panoramic radiographs (Figure 3) $[\underline{20}, \underline{117]}$. CBCT reformatted panoramic images has been shown to outperform the digital panoramic images in the identification of the MC $[118,119]$. Once, the nerve injury is confirmed, the clinician must inform the patient of IAN injury and start to treat or make a timely referral to an appropriately trained microneurosurgeon $[\underline{63}, \underline{120}]$.

\section{Stage V-treatment}

IAN injuries have a significant negative effect on the patient's quality of life and the iatrogenesis of these injuries compounds the negative psychological effects for these injuries [10]. Patients need psychological treatment: immediate information, explanation, support and realistic expectations from the treatment.

Physiological treatment includes removal of the implant, within 36 hours postsurgery [63], when it is in any contact with or causing pressure to the MC to prevent permanent damage $[\underline{15}, \underline{63}, \underline{120}]$. Subsequently, any irritants (bone debris, hematoma) in close approximation should be removed to allow faster dispersion of the haemorrhage/debris [12]. No bone grafting materials should be placed in the osteotomy site, because it may invade the MC and interfere with nerve repair [14]. If the implant causing the problem is already osseointegrated, it can be removed by a trephine drill. As an alternative, an apicoectomy of the implant

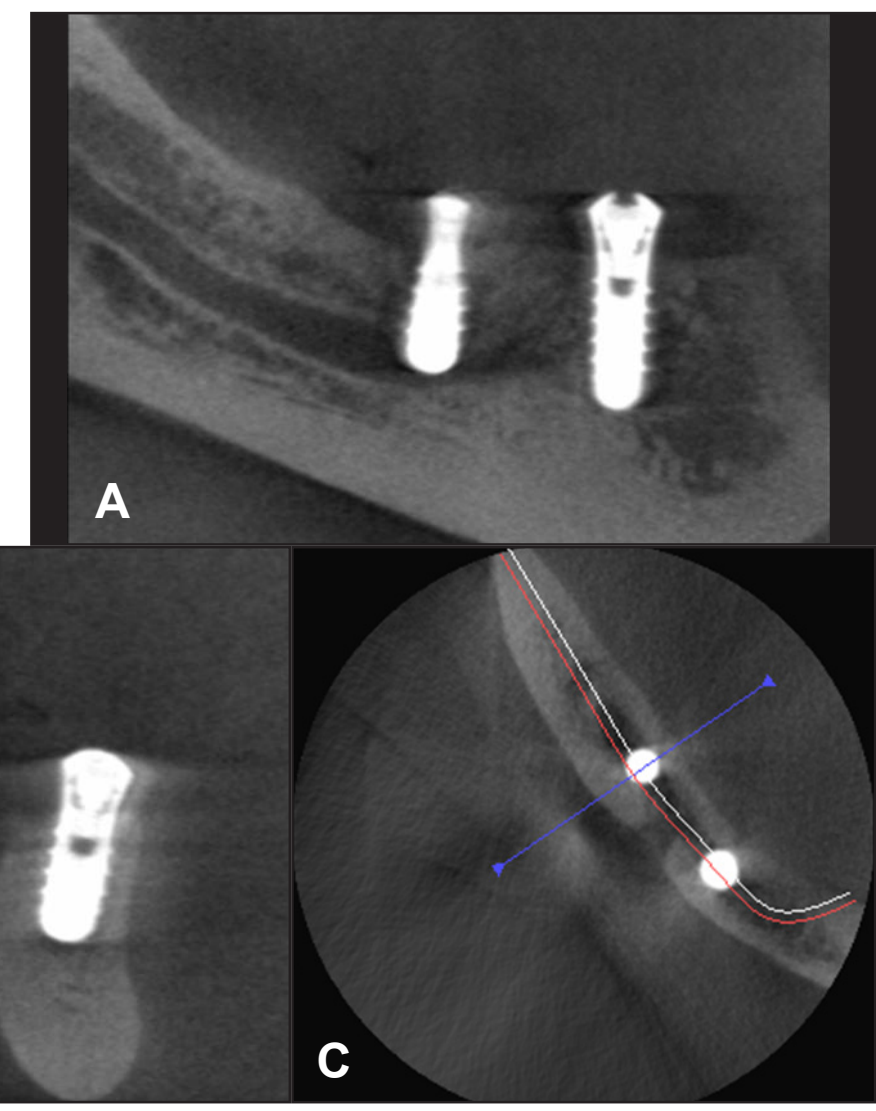

Figure 3. $\mathrm{A}=$ the orthopantomograph, $\mathrm{B}$ and $\mathrm{C}=$ cone beam computed tomography shows full dental implant intrusion into mandibular canal in 35 jaw dental segment region. There is direct mechanical trauma - IAN transection. 
can be done, if feasible [52]. Medicament treatment or the pharmacologic therapies for acute nerve injuries include the use of corticosteroids and nonsteroidal anti-inflammatory drugs (NSAIDs). The use of adrenocorticosteroids has been shown to minimize neuropathy after nerve injuries if administered in high doses within 1 week of the injury [121-123]. In addition, adrenocorticosteroids have been shown to inhibit axon sprouting centrally and ectopic discharges from injured axons and prevention of neuroma formation $[124,125]$. If during the surgery, known or observed trauma (including traction or compression of the nerve trunk) has occurred, the topical application of dexamethasone is suggested. One to two millilitres of the intravenous form of dexamethasone $(4 \mathrm{mg} / \mathrm{ml})$ maybe topically applied for 1 to 2 minutes. The direct application of adrenocorticosteroids will reduce neural inflammation and reduce compression from swelling, which may enhance recovery from neurosensory deficits [14].

The injury of peripheral nerve leads to neural sheet oedema and microcirculation disturbances because of traumatic inflammation [92]. To control inflammatory reactions in the injured nerve, a course of oral steroids can be prescribed. Oral dexamethasone $4 \mathrm{mg} 2$ tablets AM for 3 days and 1 tablet AM for next 3 days or oral prednisolone $1 \mathrm{mg}$ per $\mathrm{kg}$ per day (maximum $80 \mathrm{mg}$ ) can be indicated $[\underline{15}, \underline{16}]$. As an alternative or adjunct would be a large dose of NSAIDs drugs (such as 800 mg ibuprofen) 3 times daily for 3 weeks. If the situation improves, the clinician can prescribe another course of anti-inflammatory drugs [56]. Perceptions of pain and temperature are usually the first 2 sensations to recover, whereas other sensations may take longer [126].

Cryotherapy should be applied extraorally to most implant and bone graft sites, but especially when nerve injury is suspected. The paraneural tissues should have ice applied intensely for the first 24 hours postoperatively and then episodically for the first week [16]. Cryotherapy has been shown to minimize secondary nerve injury from the oedema-induced compression, decrease the metabolic degeneration rate of trigeminal ganglion cells from undergoing degeneration, and slow potential neuroma formation [127]. Ice, when applied to the tissues, has been shown to significantly improve postsurgical recovery [16].

In some complicated cases additional pharmacologic agents can be prescribed. They include antidepressants, anticonvulsants, antisympathetic agents, and topical medications. Additional physiologic therapies, such as transcutaneous electric nerve stimulation [128], acupuncture [129], and low level laser therapy [130], can be indicated and prescribed by a nerve specialist.

\section{Stage VI - 1 week postoperative examination}

At 1 week postoperative examination clinician should make clinical assessment of postoperative area healing, hematoma or oedema reduction and monitor IAN sensory function recovery. If paresthesia is present, neurosensory examination should be continued every week for 3 weeks and later every 2 - 3 weeks for 12 weeks.

\section{Stage VII - 1 week postoperative treatment}

At this stage of treatment patient should feel the psychological support. Medicament treatment of oral NSAIDs medication (such as ibuprofen [800 milligrams] three times per day) should be continued for 3 weeks. If necessary, the additional 3 weeks of NSAIDs may be prescribed later during 12 weeks postsurgery. Additional pharmacologic, physiologic therapies can be prescribed if indicated [56].

If IAN transection was observed intraoperatively or if there is dysesthesia or complete anaesthesia in innervation zone, referral to a microneurosurgeon and microneurosurgical treatment is indicated [131].

Patients who experience troublesome prolonged alteration in sensation may be candidates for treatment based loosely on the inclusion criteria for nerve injuries sustained by surgical procedures. The selection criteria of some authors include anaesthesia for 2 to 3 months with no improvement, paresthesia for 4 to 6 months with no improvement for 2 months or dysesthesias of minimum duration 2 to 3 months [31]. In contrast, Jones claimed that primary repair at the time of injury is the best time to repair the nerve, but it is often a closed injury and the operator does not know the nerve is injured until or after the operation [132]. Early secondary repair at about three months after injury is the most accepted time frame for repair. However, it is also thought that a reasonable result can be obtained at a later time [133]. According to Ziccardi et al., patients undergoing trigeminal nerve microsurgery for IAN injuries, 6 months after injury, derived less sensory recovery [84]. It is also, generally accepted, that the best results will be obtained with a direct anastamosis of the two ends of the nerve to be repaired. Variable results can be achieved with decompression involving external and internal neurolysis, excision with direct anastomosis or excision with placement of a nerve graft (including autogenous sural, greater auricular and medial antebrachial nerve grafts $[29,101]$, saphenous vein grafts $[17,134]$, and alloplastic Gore-Tex (W. L. Gore \& Associates, Inc., Flagstaff, AZ, USA), collagen and polyglycolic acid tubes $[29,132,135]$. Successful surgical intervention, when indicated, is generally agreed to be most predictable if performed before the onset of Wallerian degeneration (approximately 3 months) $[\underline{56}, \underline{101}, \underline{29}]$.

Strauss et al. concluded that $50 \%$ of the patients who underwent microsurgical repair of the IAN 
reported significant improvement, $42.9 \%$ reported slight improvement, and only $7.1 \%$ reported no improvement [124]. They also reported that highly significant improvements were achieved after 1 year of microsurgical intervention. Similarly Bagheri et al. concluded that microsurgical repair of peripheral branches of the trigeminal nerve injured by maxillofacial trauma produced significant improvement or complete recovery in $36(86 \%)$ of 42 patients [136].

\section{Stage VIII - 12 weeks postoperative examination}

Clinician should continue the same neurosensory examination for the patients with persisting IAN sensory function impairment.

\section{Stage IX - 12 weeks postoperative treatment}

Medicament treatment can be prescribed according to indications. For patients with no signs of IAN sensory function improvement, microneurosurgical treatment should be prescribed.

\section{CONCLUSIONS}

Damage of inferior alveolar nerve during dental implant placement can be a serious complication. Clinician should recognise and exclude aetiological factors leading to nerve injury. Proper presurgery planning, timely diagnosis and treatment are the key to avoid nerve sensory disturbances management.

\section{ACKNOWLEDGMENTS AND DISCLOSURE STATEMENTS}

The authors declare that they have no conflict of interests.

\section{REFERENCES}

1. Worthington P. Medicolegal aspects of oral implant surgery. Aust Prosthodont J. 1995;9 Suppl:13-7. [Medline: 9063137]

2. Delcanho RE. Neuropathic implications of prosthodontic treatment. J Prosthet Dent. 1995 Feb;73(2):146-52. [Medline: 7722929] [doi: 10.1016/S0022-3913(05)80154-4]

3. Rubenstein JE, Taylor TD. Apical nerve transection resulting from implant placement: a 10-year follow-up report. J Prosthet Dent. 1997 Dec;78(6):537-41. [Medline: 9421779] [doi: 10.1016/S0022-3913(97)70001-5]

4. Wismeijer D, van Waas MA, Vermeeren JI, Kalk W. Patients' perception of sensory disturbances of the mental nerve before and after implant surgery: a prospective study of 110 patients. Br J Oral Maxillofac Surg. 1997 Aug;35(4):254-9. [Medline: 9291263] [doi: 10.1016/S0266-4356(97)90043-7]

5. Dao TT, Mellor A. Sensory disturbances associated with implant surgery. Int J Prosthodont. 1998 Sep-Oct;11(5):462-9. Review. [Medline: 9922738]

6. Bartling R, Freeman K, Kraut RA. The incidence of altered sensation of the mental nerve after mandibular implant placement. J Oral Maxillofac Surg. 1999 Dec;57(12):1408-12. [Medline: 10596660] [doi: 10.1016/S0278-2391(99)90720-6]

7. Walton JN. Altered sensation associated with implants in the anterior mandible: a prospective study. J Prosthet Dent. 2000 Apr;83(4):443-9. [Medline: 10756294] [doi: 10.1016/S0022-3913(00)70039-4]

8. Ziccardi VB, Assael LA. Mechanisms of trigeminal nerve injuries. Atlas Oral Maxillofac Surg Clin North Am. 2001 Sep;9(2):1-11. [Medline: 11665372]

9. von Arx T, Häfliger J, Chappuis V. Neurosensory disturbances following bone harvesting in the symphysis: a prospective clinical study. Clin Oral Implants Res. 2005 Aug;16(4):432-9. [Medline: 16117767] [doi: $10.1111 / \mathrm{j} .1600-0501.2005 .01138 . x$ ]

10. Abarca M, van Steenberghe D, Malevez C, De Ridder J, Jacobs R. Neurosensory disturbances after immediate loading of implants in the anterior mandible: an initial questionnaire approach followed by a psychophysical assessment. Clin Oral Investig. 2006 Dec;10(4):269-77. Epub 2006 Aug 26. [Medline: 16937108] [doi: 10.1007/s00784-006-0065-0] [FREE Full Text]

11. Greenstein G, Tarnow D. The mental foramen and nerve: clinical and anatomical factors related to dental implant placement: a literature review. J Periodontol. 2006 Dec;77(12):1933-43. Review. [Medline: 17209776] [doi: 10.1902/jop.2006.060197]

12. Hegedus F, Diecidue RJ. Trigeminal nerve injuries after mandibular implant placement--practical knowledge for clinicians. Int J Oral Maxillofac Implants. 2006 Jan-Feb;21(1):111-6. Review. [Medline: 16519189]

13. Tay AB, Zuniga JR. Clinical characteristics of trigeminal nerve injury referrals to a university centre. Int J Oral Maxillofac Surg. 2007 Oct;36(10):922-7. Epub 2007 Sep 17. [Medline: 17875382] [doi: 10.1016/j.ijom.2007.03.012]

14. Misch CE. Root form surgery in the edentulous anterior and posterior mandible: Implant insertion. In: Misch CE, ed. Contemporary Implant Dentistry. St. Louis, MO: Mosby Elsevier; 2008. P. 221-226.

15. Alhassani AA, AlGhamdi AS. Inferior alveolar nerve injury in implant dentistry: diagnosis, causes, prevention, and management. J Oral Implantol. 2010;36(5):401-7. Epub 2010 Jun 14. Review. [Medline: 20545547] [doi: 10.1563/AAID-JOI-D-09-00059]

16. Misch CE, Resnik R. Mandibular nerve neurosensory impairment after dental implant surgery: management and protocol. Implant Dent. 2010 Oct;19(5):378-86. [Medline: 20881808] [doi: 10.1097/ID.0b013e3181effa92]

17. Pogrel MA, Maghen A. The use of autogenous vein grafts for inferior alveolar and lingual nerve reconstruction. J Oral Maxillofac Surg. 2001 Sep;59(9):985-8; discussion 988-93. [Medline: 11526560] [doi: 10.1053/joms.2001.25821]

18. Juodzbalys G, Wang HL, Sabalys G. Anatomy of Mandibular Vital Structures. Part I: Mandibular Canal and Inferior Alveolar Neurovascular Bundle in relation with Dental Implantology. J Oral Maxillofac Res 2010;1(1):e2. [URL: http://www.ejomr.org/JOMR/archives/2010/1/e2/e2ht.htm] [doi: 10.5037/jomr.2010.1102] 
19. Juodzbalys G, Wang HL, Sabalys G. Anatomy of Mandibular Vital Structures. Part II: Mandibular Incisive Canal, Mental Foramen and Associated Neurovascular Bundles in Relation with Dental Implantology. J Oral Maxillofac Res 2010;1(1):e3. [URL: http://www.ejomr.org/JOMR/archives/2010/1/e3/e3ht.htm] [doi: 10.5037/jomr.2010.1103]

20. Juodzbalys G, Wang HL. Guidelines for the Identification of the Mandibular Vital Structures: Practical Clinical Applications of Anatomy and Radiological Examination Methods. J Oral Maxillofac Res 2010;1(2):e1. [URL: http://www.ejomr.org/JOMR/archives/2010/2/e1/e1ht.htm] [doi: 10.5037/jomr.2010.1201]

21. Malamed SF. Nerve injury caused by mandibular block analgesia. Int J Oral Maxillofac Surg. 2006 Sep;35(9):876-7; author reply 878. Epub 2006 Jul 7. [Medline: 16829034] [doi: 10.1016/j.ijom.2006.03.022]

22. Malamed SF. Local anesthesia reversal. Dent Today. 2010 Mar;29(3):65-6, 68, 71-2 passim; quiz 74. [Medline: 20333856]

23. Kramer HS Jr, Mitton VA. Complications of local anesthesia. Dent Clin North Am. 1973 Jul;17(3):443-60. [Medline: 4513764]

24. Harn SD, Durham TM. Incidence of lingual nerve trauma and postinjection complications in conventional mandibular block anesthesia. J Am Dent Assoc. 1990 Oct;121(4):519-23. [Medline: 2212345]

25. Krafft TC, Hickel R. Clinical investigation into the incidence of direct damage to the lingual nerve caused by local anaesthesia. J Craniomaxillofac Surg. 1994 Oct;22(5):294-6. [Medline: 7798361] [doi: 10.1016/S1010-5182(05)80079-4]

26. Paxton MC, Hadley JN, Hadley MN, Edwards RC, Harrison SJ. Chorda tympani nerve injury following inferior alveolar injection: a review of two cases. J Am Dent Assoc. 1994 Jul;125(7):1003-6. [Medline: $\underline{8040522]}$

27. Haas DA, Lennon D. A 21 year retrospective study of reports of paresthesia following local anesthetic administration. J Can Dent Assoc. 1995 Apr;61(4):319-20, 323-6, 329-30. [Medline: 7736335]

28. Pogrel MA, Bryan J, Regezi J. Nerve damage associated with inferior alveolar nerve blocks. J Am Dent Assoc. 1995 Aug;126(8):1150-5. [Medline: 7560573]

29. Ruggiero SL. Trigeminal nerve injury and repair. N Y State Dent J. 1996 Oct;62(8):36-40. Review. [Medline: 8909045]

30. Lustig JP, Zusman SP. Immediate complications of local anesthetic administered to 1,007 consecutive patients. J Am Dent Assoc. 1999 Apr;130(4):496-9. [Medline: 10203899]

31. Pogrel MA, Thamby S. The etiology of altered sensation in the inferior alveolar, lingual, and mental nerves as a result of dental treatment. J Calif Dent Assoc. 1999 Jul;27(7):531, 534-8. [Medline: 10530111]

32. Chang WK, Mulford GJ. Iatrogenic trigeminal sensorimotor neuropathy resulting from local anesthesia: a case report. Arch Phys Med Rehabil. 2000 Dec;81(12):1591-3. [Medline: 11128895] [doi: 10.1053/apmr.2000.6974]

33. Pogrel MA, Thamby S. Permanent nerve involvement resulting from inferior alveolar nerve blocks. J Am Dent Assoc. 2000 Jul;131(7):901-7. Erratum in: J Am Dent Assoc 2000 Oct;131(10):1418. [Medline: 10916328]

34. Smith MH, Lung KE. Nerve injuries after dental injection: a review of the literature. J Can Dent Assoc. 2006 JulAug;72(6):559-64. Review. [Medline: 16884649] [FREE Full Text]

35. Pogrel MA. Summary of: Trigeminal nerve injuries in relation to the local anaesthesia in mandibular injections. Br Dent J. 2010 Nov;209(9):452-3. [Medline: 21072098] [doi: 10.1038/sj.bdj.2010.1009]

36. Renton T, Adey-Viscuso D, Meechan JG, Yilmaz Z. Trigeminal nerve injuries in relation to the local anaesthesia in mandibular injections. Br Dent J. 2010 Nov;209(9):E15. [Medline: 21072069] [doi: 10.1038/sj.bdj.2010.978]

37. Wyman RJ. Nerve injury following a mandibular block: a case report. Dent Today. 2010 Jul;29(7):14; author reply 14. [Medline: 20687431]

38. Stacy GC, Hajjar G. Barbed needle and inexplicable paresthesias and trismus after dental regional anesthesia. Oral Surg Oral Med Oral Pathol. 1994 Jun;77(6):585-8. [Medline: 8065720] [doi: 10.1016/0030-4220(94)90315-8]

39. Crean SJ, Powis A. Neurological complications of local anaesthetics in dentistry. Dent Update. 1999 Oct;26(8):344-9. [Medline: 10765749$]$

40. Pogrel MA, Kaban LB. Injuries to the inferior alveolar and lingual nerves. J Calif Dent Assoc. 1993 Jan;21(1):50-4. [Medline: $\underline{7682607]}$

41. Nickel AA Jr. A retrospective study of paresthesia of the dental alveolar nerves. Anesth Prog. 1990 Jan-Feb;37(1):42-5. [Medline: 2077986] [FREE Full Text]

42. Saray A, Apan A, Kisa U. Free radical-induced damage in experimental peripheral nerve injection injury. J Reconstr Microsurg. 2003 Aug;19(6):401-6. [Medline: 14515234] [doi: 10.1055/s-2003-42637]

43. Kirihara Y, Saito Y, Sakura S, Hashimoto K, Kishimoto T, Yasui Y. Comparative neurotoxicity of intrathecal and epidural lidocaine in rats. Anesthesiology. 2003 Oct;99(4):961-8. [Medline: 14508332] [doi: 10.1097/00000542-200310000-00032]

44. Hillerup S, Jensen R. Nerve injury caused by mandibular block analgesia. Int J Oral Maxillofac Surg. 2006 May;35(5):43743. Epub 2005 Dec 15. [Medline: 16343853] [doi: 10.1016/j.ijom.2005.10.004]

45. Gaffen AS, Haas DA. Retrospective review of voluntary reports of nonsurgical paresthesia in dentistry. J Can Dent Assoc. 2009 Oct;75(8):579. [Medline: 19840499] [FREE Full Text]

46. Loescher AR, Robinson PP. The effect of surgical medicaments on peripheral nerve function. Br J Oral Maxillofac Surg. 1998 Oct;36(5):327-32. [Medline: 9831051] [doi: 10.1016/S0266-4356(98)90642-8]

47. Ribeiro PD Jr, Sanches MG, Okamoto T. Comparative analysis of tissue reactions to anesthetic solutions: histological analysis in subcutaneous tissue of rats. Anesth Prog. 2003;50(4):169-80. [Medline: 14959905] [FREE Full Text] 
48. Perez-Castro R, Patel S, Garavito-Aguilar ZV, Rosenberg A, Recio-Pinto E, Zhang J, Blanck TJ, Xu F. Cytotoxicity of local anesthetics in human neuronal cells. Anesth Analg. 2009 Mar;108(3):997-1007. [Medline: 19224816] [doi: 10.1213/ane.0b013e31819385e1] [FREE Full Text]

49. Malamed S. What's new in local anaesthesia? SAAD Dig. 2009 Jan;25:4-14. [Medline: 19267135]

50. Torrente-Castells E, Gargallo-Albiol J, Rodríguez-Baeza A, Berini-Aytés L, Gay-Escoda C. Necrosis of the skin of the chin: a possible complication of inferior alveolar nerve block injection. J Am Dent Assoc. 2008 Dec;139(12):1625-30. [Medline: 19047668]

51. Heller AA, Shankland WE 2nd. Alternative to the inferior alveolar nerve block anesthesia when placing mandibular dental implants posterior to the mental foramen. J Oral Implantol. 2001;27(3):127-33. [Medline: 12500871] [doi: 10.1563/1548-1336(2001)027<0127:ATTIAN $>2.3 . C O ; 2]$

52. Levitt DS. Apicoectomy of an endosseous implant to relieve paresthesia: a case report. Implant Dent. 2003;12(3):202-5. [Medline: 14560478$]$

53. Héraud J, Orofino J, Trub M, Mei N. Electrophysiologic evidence showing the existence of sensory receptors within the alveolar bone in anesthetized cats. Int J Oral Maxillofac Implants. 1996 Nov-Dec;11(6):800-5. [Medline: $\underline{8990644]}$

54. Worthington P. Injury to the inferior alveolar nerve during implant placement: a formula for protection of the patient and clinician. Int J Oral Maxillofac Implants. 2004 Sep-Oct;19(5):731-4. [Medline: $\underline{15508990]}$

55. Nazarian Y, Eliav E, Nahlieli O. [Nerve injury following implant placement: prevention, diagnosis and treatment modalities]. Refuat Hapeh Vehashinayim. 2003 Jul;20(3):44-50, 101. Hebrew. [Medline: 14515628]

56. Kraut RA, Chahal O. Management of patients with trigeminal nerve injuries after mandibular implant placement. J Am Dent Assoc. 2002 Oct;133(10):1351-4. [Medline: 12403537]

57. Başa O, Dilek OC. Assessment of the risk of perforation of the mandibular canal by implant drill using density and thickness parameters. Gerodontology. 2010 Mar 4. [Epub ahead of print] [Medline: 20236331]

58. Theisen FC, Shultz RE, Elledge DA. Displacement of a root form implant into the mandibular canal. Oral Surg Oral Med Oral Pathol. 1990 Jul;70(1):24-8. [Medline: 2196504] [doi: 10.1016/0030-4220(90)90172-O]

59. Fanuscu MI, Chang TL. Three-dimensional morphometric analysis of human cadaver bone: microstructural data from maxilla and mandible. Clin Oral Implants Res. 2004 Apr;15(2):213-8. [Medline: 15008933] [doi: 10.1111/j.1600-0501.2004.00969.x]

60. Schwarz MS, Rothman SL, Rhodes ML, Chafetz N. Computed tomography: Part I. Preoperative assessment of the mandible for endosseous implant surgery. Int J Oral Maxillofac Implants. 1987 Summer;2(3):137-41. [Medline: 3481354$]$

61. Gaggl A, Schultes G, Kärcher H. Navigational precision of drilling tools preventing damage to the mandibular canal. J Craniomaxillofac Surg. 2001 Oct;29(5):271-5. [Medline: 11673921] [doi: 10.1054/jcms.2001.0239]

62. Burstein J, Mastin C, Le B. Avoiding injury to the inferior alveolar nerve by routine use of intraoperative radiographs during implant placement. J Oral Implantol. 2008;34(1):34-8. [Medline: 18390241] [doi: 10.1563/1548-1336(2008)34[34:AITTIA]2.0.CO;2]

63. Khawaja N, Renton T. Case studies on implant removal influencing the resolution of inferior alveolar nerve injury. Br Dent J. 2009 Apr 11;206(7):365-70. [Medline: 19357667] [doi: 10.1038/sj.bdj.2009.258]

64. Lamas Pelayo J, Peñarrocha Diago M, Martí Bowen E, Peñarrocha Diago M. Intraoperative complications during oral implantology. Med Oral Patol Oral Cir Bucal. 2008 Apr 1;13(4):E239-43. Review. [Medline: 18379448] [FREE Full Text]

65. Fanibunda K, Whitworth J, Steele J. The management of thermomechanically compacted gutta percha extrusion in the inferior dental canal. Br Dent J. 1998 Apr 11;184(7):330-2. [Medline: 9599885]

66. Tehemar SH. Factors affecting heat generation during implant site preparation: a review of biologic observations and future considerations. Int J Oral Maxillofac Implants. 1999 Jan-Feb;14(1):127-36. Review. [Medline: 10074763]

67. Eriksson AR, Albrektsson T. Temperature threshold levels for heat-induced bone tissue injury: a vital-microscopic study in the rabbit. J Prosthet Dent. 1983 Jul;50(1):101-7. [Medline: 6576145] [doi: 10.1016/0022-3913(83)90174-9]

68. Eriksson RA, Albrektsson T. The effect of heat on bone regeneration: an experimental study in the rabbit using the bone growth chamber. J Oral Maxillofac Surg. 1984 Nov;42(11):705-11. [Medline: 6593442] [doi: 10.1016/0278-2391(84)90417-8]

69. Benington IC, Biagioni PA, Briggs J, Sheridan S, Lamey PJ. Thermal changes observed at implant sites during internal and external irrigation. Clin Oral Implants Res. 2002 Jun;13(3):293-7. [Medline: 12010160] [doi: 10.1034/j.1600-0501.2002.130309.x]

70. Beirowski B, Adalbert R, Wagner D, Grumme DS, Addicks K, Ribchester RR, Coleman MP. The progressive nature of Wallerian degeneration in wild-type and slow Wallerian degeneration (WldS) nerves. BMC Neurosci. 2005 Feb 1;6:6. [Medline: 15686598] [doi: 10.1186/1471-2202-6-6] [FREE Full Text]

71. Leckel M, Kress B, Schmitter M. Neuropathic pain resulting from implant placement: case report and diagnostic conclusions. J Oral Rehabil. 2009 Jul;36(7):543-6. Epub 2009 Mar 17. [Medline: 19490376] [doi: 10.1111/j.1365-2842.2009.01950.x]

72. Sammartino G, Marenzi G, Citarella R, Ciccarelli R, Wang HL. Analysis of the occlusal stress transmitted to the inferior alveolar nerve by an osseointegrated threaded fixture. J Periodontol. 2008 Sep;79(9):1735-44. [Medline: 18771376] [doi: 10.1902/jop.2008.080030] 
73. Guan H, van Staden R, Loo YC, Johnson N, Ivanovski S, Meredith N. Influence of bone and dental implant parameters on stress distribution in the mandible: a finite element study. Int J Oral Maxillofac Implants. 2009 Sep-Oct;24(5):866-76. [Medline: 19865627$]$

74. Peñarrocha Diago M, Boronat López A, Lamas Pelayo J. Update in dental implant periapical surgery. Med Oral Patol Oral Cir Bucal. 2006 Aug 1;11(5):E429-32. Review. English, Spanish. [Medline: 16878068] [FREE Full Text]

75. Elian N, Mitsias M, Eskow R, Jalbout ZN, Cho SC, Froum S, Tarnow DP. Unexpected return of sensation following 4.5 years of paresthesia: case report. Implant Dent. 2005 Dec;14(4):364-7. [Medline: 16361887]

76. Jacobs R, Lambrichts I, Liang X, Martens W, Mraiwa N, Adriaensens P, Gelan J. Neurovascularization of the anterior jaw bones revisited using high-resolution magnetic resonance imaging. Oral Surg Oral Med Oral Pathol Oral Radiol Endod. 2007 May;103(5):683-93. Epub 2007 Feb 22. [Medline: 17320428] [doi: 10.1016/j.tripleo.2006.11.014]

77. Ulm CW, Solar P, Blahout R, Matejka M, Watzek G, Gruber H. Location of the mandibular canal within the atrophic mandible. Br J Oral Maxillofac Surg. 1993 Dec;31(6):370-5. [Medline: 8286291] [doi: 10.1016/0266-4356(93)90193-Z]

78. Mraiwa N, Jacobs R, Moerman P, Lambrichts I, van Steenberghe D, Quirynen M. Presence and course of the incisive canal in the human mandibular interforaminal region: two-dimensional imaging versus anatomical observations. Surg Radiol Anat. 2003 Nov-Dec;25(5-6):416-23. Epub 2003 Sep 11. [Medline: 13680184] [doi: 10.1007/s00276-003-0152-8]

79. Gershenson A, Nathan H, Luchansky E. Mental foramen and mental nerve: changes with age. Acta Anat (Basel). 1986;126(1):21-8. [Medline: 3739599] [doi: 10.1159/000146181]

80. Cranin AN. Implant surgery: the management of soft tissues. J Oral Implantol. 2002;28(5):230-7. [Medline: 12498472] [doi: 10.1563/1548-1336(2002)028<0230:ISTMOS>2.3.CO;2]

81. Gregg JM. Neuropathic complications of mandibular implant surgery: review and case presentations. Ann R Australas Coll Dent Surg. 2000 Oct;15:176-80. Review. [Medline: 11709934]

82. Ellies LG, Hawker PB. The prevalence of altered sensation associated with implant surgery. Int J Oral Maxillofac Implants. 1993;8(6):674-9. [Medline: $\underline{8181830]}$

83. Hubbard JH. The quality of nerve regeneration. Factors independent of the most skillful repair. Surg Clin North Am. 1972 Oct;52(5):1099-108. Review. [Medline: 4342479]

84. Jääskeläinen SK, Teerijoki-Oksa T, Forssell H. Neurophysiologic and quantitative sensory testing in the diagnosis of trigeminal neuropathy and neuropathic pain. Pain. 2005 Oct;117(3):349-57. [Medline: 16153774]

85. Bruce RA, Frederickson GC, Small GS. Age of patients and morbidity associated with mandibular third molar surgery. J Am Dent Assoc. 1980 Aug;101(2):240-5. [Medline: 6931159]

86. Rood JP, Shehab BA. The radiological prediction of inferior alveolar nerve injury during third molar surgery. Br J Oral Maxillofac Surg. 1990 Feb;28(1):20-5. [Medline: 2322523] [doi: 10.1016/0266-4356(90)90005-6]

87. Cooper BY, Sessle GJ. Anatomy, physiology, and pathophysiology of trigeminal system paresthesias and dysesthesias. Oral Maxillofac Surg Clin N Am. 1992;4:297-322.

88. Shimpo T, Gilliatt RW, Kennett RP, Allen PJ. Susceptibility to pressure neuropathy distal to a constricting ligature in the guinea-pig. J Neurol Neurosurg Psychiatry. 1987 Dec;50(12):1625-32. [Medline: 2830368] [doi: 10.1136/jnnp.50.12.1625] [ [FREE Full Text]

89. Ziccardi VB, Rivera L, Gomes J. Comparison of lingual and inferior alveolar nerve microsurgery outcomes. Quintessence Int. 2009 Apr;40(4):295-301. [Medline: 19417874]

90. Yekta SS, Smeets R, Stein JM, Ellrich J. Assessment of trigeminal nerve functions by quantitative sensory testing in patients and healthy volunteers. J Oral Maxillofac Surg. 2010 Oct;68(10):2437-51. Epub 2010 Jul 3. [Medline: 20598414] [doi: 10.1016/j.joms.2009.12.013]

91. Seddon HJ. Three types of nerve injury. Brain. 1943; 66:247-288. [doi: 10.1093/brain/66.4.237] [FREE Full Text]

92. LaBanc JP. Trigeminal nerve injury: diagnosis and management. Oral Maxillofac Clin North Am. 1992; 4:285-296.

93. Sunderland S. A classification of peripheral nerve injuries producing loss of function. Brain. 1951 Dec;74(4):491-516. [Medline: 14895767] [doi: 10.1093/brain/74.4.491] [ [FREE Full Text]

94. Rappaport ZH, Devor M. Trigeminal neuralgia: the role of self-sustaining discharge in the trigeminal ganglion. Pain. 1994 Feb;56(2):127-38. Review. [Medline: 8008402]

95. Rood JP. Degrees of injury to the inferior alveolar nerve sustained during the removal of impacted mandibular third molars by the lingual split technique. Br J Oral Surg. 1983 Jun;21(2):103-16. [Medline: 6575812] [doi: 10.1016/0007-117X(83)90054-9]

96. Robinson PP, Loescher AR, Smith KG. A prospective, quantitative study on the clinical outcome of lingual nerve repair. Br J Oral Maxillofac Surg. 2000 Aug;38(4):255-63. [Medline: 10922146] [doi: 10.1054/bjom.2000.0463]

97. American Academy of Implant Dentistry. Glossary of implant terms. J Oral Implantol. 1986;12(2):284-94. [Medline: $\underline{\text { 3519998] }}$

98. Tal M. A Role for Inflammation in Chronic Pain. Curr Rev Pain. 1999;3(6):440-446. [Medline: 10998702]

99. Mraiwa N, Jacobs R, Moerman P, Lambrichts I, van Steenberghe D, Quirynen M. Presence and course of the incisive canal in the human mandibular interforaminal region: two-dimensional imaging versus anatomical observations. Surg Radiol Anat. 2003 Nov-Dec;25(5-6):416-23. Epub 2003 Sep 11. [Medline: 13680184] [doi: 10.1007/s00276-003-0152-8]

100. Roy TS, Sarkar AK, Panicker HK. Variation in the origin of the inferior alveolar nerve. Clin Anat. 2002 Mar;15(2):143-7. [Medline: 11877794] [doi: 10.1002/ca.1110] 
101. Colin W, Donoff RB. Restoring sensation after trigeminal nerve injury: a review of current management. J Am Dent Assoc. 1992 Dec;123(12):80-5. Review. [Medline: 1309192]

102. Merskey H, Bogduk N, (eds). Classification of Chronic Pain. 2nd ed. International Association for the Study of Pain Task Force on Taxonomy, IASP Press IASP Councilin Kyoto; November 29-30, 2007.

103. Ylikontiola L, Kinnunen J, Oikarinen K. Comparison of different tests assessing neurosensory disturbances after bilateral sagittal split osteotomy. Int J Oral Maxillofac Surg. 1998 Dec;27(6):417-21. [Medline: 9869278] [doi: 10.1016/S0901-5027(98)80028-3]

104. Ylikontiola L, Kinnunen J, Laukkanen P, Oikarinen K. Prediction of recovery from neurosensory deficit after bilateral sagittal split osteotomy. Oral Surg Oral Med Oral Pathol Oral Radiol Endod. 2000 Sep;90(3):275-81. [Medline: 10982946] [doi: $10.1067 /$ moe.2000.108920]

105. Ylikontiola L, Vesala J, Oikarinen K. Repeatability of 5 clinical neurosensory tests used in orthognathic surgery. Int J Adult Orthodon Orthognath Surg. 2001;16(1):36-46. [Medline: 11563394]

106.Loescher AR, Smith KG, Robinson PP. Nerve damage and third molar removal. Dent Update. 2003 Sep;30(7):375-80, 382. Review. [Medline: 14558203]

107. Kawamura P, Wessberg GA. Normal trigeminal neurosensory responses. Hawaii Dent J. 1985 Apr;16(4):8-11. [Medline: $\underline{3864769}$ ]

108. Walter JM Jr, Gregg JM. Analysis of postsurgical neurologic alteration in the trigeminal nerve. J Oral Surg. 1979 Jun;37(6):410-4. [Medline: 220400]

109. Nakagawa K, Ueki K, Takatsuka S, Takazakura D, Yamamoto E. Somatosensory-evoked potential to evaluate the trigeminal nerve after sagittal split osteotomy. Oral Surg Oral Med Oral Pathol Oral Radiol Endod. 2001 Feb;91(2):146-52. [Medline: 11174589] [doi: 10.1067/moe.2001.112331]

110. Jones DL, Wolford LM, Hartog JM. Comparison of methods to assess neurosensory alterations following orthognathic surgery. Int J Adult Orthodon Orthognath Surg. 1990;5(1):35-42. [Medline: 2373911]

111. Jääskeläinen SK, Peltola JK, Forssell K, Vähätalo K. Evaluating function of the inferior alveolar nerve with repeated nerve conduction tests during mandibular sagittal split osteotomy. J Oral Maxillofac Surg. 1995 Mar;53(3):269-79. [Medline: 7861277] [doi: 10.1016/0278-2391(95)90223-6]

112. Jääskeläinen SK, Teerijoki-Oksa T, Forssell K, Vähätalo K, Peltola JK, Forssell H. Intraoperative monitoring of the inferior alveolar nerve during mandibular sagittal-split osteotomy. Muscle Nerve. 2000 Mar;23(3):368-75. [Medline: 10679713] [doi: 10.1002/(SICI)1097-4598(200003)23:3<368::AID-MUS8>3.0.CO;2-0]

113. Colin WB. Conduction velocity of the human inferior alveolar nerve. Normative data. Arch Otolaryngol Head Neck Surg. 1997 Feb;123(2):185-9. [Medline: 9046287]

114. Kugelberg E. [Facial reflexes]. Brain. 1952 Sep;75(3):385-96. [Medline: 12978170] [doi: 10.1093/brain/75.3.385]

115. Jääskeläinen SK, Peltola JK. Clinical application of the blink reflex with stimulation of the mental nerve in lesions of the inferior alveolar nerve. Neurology. 1994 Dec;44(12):2356-61. [Medline: 7991126]

116. Jääskeläinen SK. Blink reflex with stimulation of the mental nerve. Methodology, reference values, and some clinical vignettes. Acta Neurol Scand. 1995 Jun;91(6):477-82. [Medline: 7572043] [doi: 10.1111/j.1600-0404.1995.tb00449.x]

117. Worthington P, Rubenstein J, Hatcher DC. The role of cone-beam computed tomography in the planning and placement of implants. J Am Dent Assoc. 2010 Oct;141 Suppl 3:19S-24S. [Medline: 20884936]

118. Angelopoulos C, Thomas SL, Hechler S, Parissis N, Hlavacek M. Comparison between digital panoramic radiography and cone-beam computed tomography for the identification of the mandibular canal as part of presurgical dental implant assessment. J Oral Maxillofac Surg. 2008 Oct;66(10):2130-5. Erratum in: J Oral Maxillofac Surg. 2008 Dec;66(12):2657. [Medline: 18848113 ] [doi: 10.1016/j.joms.2008.06.021]

119. Kamburoğlu K, Kiliç C, Ozen T, Yüksel SP. Measurements of mandibular canal region obtained by cone-beam computed tomography: a cadaveric study. Oral Surg Oral Med Oral Pathol Oral Radiol Endod. 2009 Feb;107(2):e34-42. [Medline: 19138636] [doi: 10.1016/j.tripleo.2008.10.012]

120. Renton T. Prevention of iatrogenic inferior alveolar nerve injuries in relation to dental procedures. Dent Update. 2010 Jul-Aug;37(6):350-2, 354-6, 358-60 passim. Review. [Medline: 20929149]

121. Galloway EB 3rd, Jensen RL, Dailey AT, Thompson BG, Shelton C. Role of topical steroids in reducing dysfunction after nerve injury. Laryngoscope. 2000 Nov;110(11):1907-10. [Medline: 11081608] [doi: 10.1097/00005537-200011000-00026]

122.Jancsó G, Kiraly E, Jancsó-Gábor A. Pharmacologically induced selective degeneration of chemosensitive primary sensory neurones. Nature. 1977 Dec 22-29;270(5639):741-3. [Medline: 593396] [doi: 10.1038/270741a0]

123. Han SR, Yeo SP, Lee MK, Bae YC, Ahn DK. Early dexamethasone relieves trigeminal neuropathic pain. J Dent Res. 2010 Sep;89(9):915-20. Epub 2010 Jun 25. [Medline: 20581355] [doi: 10.1177/0022034510374056]

124. Kohnelein KE, Ocker K, Seitz HD. Experimental rails to inhibit neuroma formation. Chir Plast (Berl). 1980;5:207-211.

125.Seo K, Tanaka Y, Terumitsu M, Someya G. Efficacy of steroid treatment for sensory impairment after orthognathic surgery. J Oral Maxillofac Surg. 2004 Oct;62(10):1193-7. [Medline: 15452804] [doi: 10.1016/j.joms.2004.06.033]

126. Strauss ER, Ziccardi VB, Janal MN. Outcome assessment of inferior alveolar nerve microsurgery: a retrospective review. J Oral Maxillofac Surg. 2006 Dec;64(12):1767-70. [Medline: 17113443] [doi: 10.1016/j.joms.2005.11.111] 
127. Olson JE, Stravino VD. A review of cryotherapy. Phys Ther. 1972 Aug;52(8):840-53. Review. [Medline: 4558889]

128. Bates JAV, Nathan PW. Transcuaneous electrical nerve stimulation for chronic pain. Anaesthesia. 1980;35:817-824. [doi: $10.1111 / \mathrm{j} .1365-2044.1980$. tb03926.x]

129. Sung YF, Kutner MH, Cerine FC, Frederickson EL. Comparison of the effects of acupuncture and codeine on postoperative dental pain. Anesth Analg. 1977 Jul-Aug;56(4):473-8. [Medline: 327853] [doi: 10.1213/00000539-197707000-00001]

130.Poole TE, Holland I, Peterson LJ. Clinical efficacy of low level laser treatment of oro-facial neurosensory deficits. J Oral Maxillofac Surg. 1993;51(suppl3): 182-6.

131. Hillerup S. Iatrogenic injury to the inferior alveolar nerve: etiology, signs and symptoms, and observations on recovery. Int J Oral Maxillofac Surg. 2008 Aug;37(8):704-9. Epub 2008 May 23. [Medline: 18501561] [doi: 10.1016/j.ijom.2008.04.002]

132.Pogrel MA. The results of microneurosurgery of the inferior alveolar and lingual nerve. J Oral Maxillofac Surg. 2002 May;60(5):485-9. [Medline: 11988920] [doi: 10.1053/joms.2002.31841]

133.Jones RH. Repair of the trigeminal nerve: a review. Aust Dent J. 2010 Jun;55(2):112-9. Review. [Medline: 20604750] [doi: $10.1111 / \mathrm{j} .1834-7819.2010 .01216 . \mathrm{x}$ ]

134.Jones RH. The use of vein grafts in the repair of the inferior alveolar nerve following surgery. Aust Dent J. 2010 Jun;55(2):207-13. [Medline: 20604766] [doi: 10.1111/j.1834-7819.2010.01215.x]

135. Farole A, Jamal BT. A bioabsorbable collagen nerve cuff (NeuraGen) for repair of lingual and inferior alveolar nerve injuries: a case series. J Oral Maxillofac Surg. 2008 Oct;66(10):2058-62. [Medline: 18848102] [doi: 10.1016/j.joms.2008.06.017]

136. Bagheri SC, Meyer RA, Khan HA, Steed MB. Microsurgical repair of peripheral trigeminal nerve injuries from maxillofacial trauma. J Oral Maxillofac Surg. 2009 Sep;67(9):1791-9. [Medline: 19686912] [doi: 10.1016/i.joms.2009.04.115]

\section{To cite this article:}

Juodzbalys G, Wang HL, Sabalys G. Injury of the Inferior Alveolar Nerve during Implant Placement: a Literature Review.

J Oral Maxillofac Res 2011;2(1):e1

URL: http://www.ejomr.org/JOMR/archives/2011/1/e1/v2n1e1ht.pdf

doi: $10.5037 /$ jomr.2011.2101

Copyright (C) Juodzbalys G, Wang HL, Sabalys G. Accepted for publication in the JOURNAL OF ORAL \& MAXILLOFACIAL RESEARCH (http://www.ejomr.org), 10 January 2011.

This is an open-access article, first published in the JOURNAL OF ORAL \& MAXILLOFACIAL RESEARCH, distributed under the terms of the Creative Commons Attribution-Noncommercial-No Derivative Works 3.0 Unported License, which permits unrestricted non-commercial use, distribution, and reproduction in any medium, provided the original work and is properly cited. The copyright, license information and link to the original publication on (http://www.ejomr.org) must be included. 